\title{
Valence as Macro-Competence: An Analysis of Mood in Party Competence Evaluations in Great Britain
}

\author{
JANE GREEN AND WILL JENNINGS*
}

There is a discernable mood in macro-level public evaluations of party issue competence. This paper argues that voters use heuristics to transfer issue competence ratings of parties between issues, therefore issue competence ratings move in common. Events, economic shocks and the costs of governing reinforce these shared dynamics. These expectations are analysed using issue competence data in Britain 1950-2008, and using Stimson's dyad ratios algorithm to estimate 'macro-competence'. Effects on macro-competence are found for events and economic shocks, time in government, leader ratings, economic evaluations and partisanship, but macro-competence also accounts for unique variance in a model of party choice. The article presents an aggregate-level time-series measure to capture the longterm dynamics of 'valence'.

Policy performance and party competence reputations are important prerequisites for electoral success, with issue-by-issue party and candidate ratings forming central components of electoral campaigns. ${ }^{1}$ The competence, handling and trust ratings of parties and candidates on issues represent an electoral battleground. ${ }^{2}$ Stokes argued that

* School of Social Sciences, University of Manchester (email: jane.green@manchester.ac.uk). The authors wish to thank John Bartle and David Sanders for sharing data, Jim Stimson for his assistance with the dyad ratios algorithm, and Ian Budge, Mathew Lebo and Michael Lewis-Beck, as well as the anonymous reviewers of this journal, for their invaluable comments on earlier versions of this article.

1 John R. Petrocik, 'Issue Ownership in Presidential Elections, with a 1980 Case Study', American Journal of Political Science, 40 (1996), 825-50; John R. Petrocik, William L. Benoit and Glenn J. Hansen, 'Issue Ownership and Presidential Campaigning, 1952-2000', Political Science Quarterly, 118 (2003), 4, 599-626; James N. Druckman, 'Priming the Vote: Campaign Effects in a U.S. Senate Election', Political Psychology, 25 (2004), 4, 577-94; David B. Holian, 'He's Stealing My Issues! Clinton's Crime Rhetoric and the Dynamics of Issue Ownership', Political Behavior, 26 (2004), 95-124; Lawrence R. Jacobs and Robert Y. Shapiro, 'Issues, Candidate Image, and Priming', American Political Science Review, 88 (1994), 527-40.

2 Ian Budge and Dennis Farlie, Explaining and Predicting Elections: Issue Effects and Party Strategies in Twenty-Three Democracies (London: Allen \& Unwin, 1983), p. 226; Ian Budge, 'The Internal Analysis of Election Programmes', in Ian Budge, Derek Hearl and David Robertson, eds., Ideology, Strategy and Party Change: Spatial Analysis of Post-War Election Programmes in 19 Democracies (Cambridge: Cambridge University Press, 1987), pp. 15-38; Ian Budge, Hans-Dieter Klingemann, Andrea Volkens, Judith Bara and Eric Tannenbaum, eds., Mapping Policy Preferences (Oxford: Oxford University Press, 2001); William H. Riker, Agenda Formation (Ann Arbor: University of Michigan Press, 1993), pp. 285; Petrocik, 'Issue Ownership in Presidential Elections'; Petrocik et al., 'Issue Ownership and Presidential Campaigning'; Adam F. Simon, The Winning Message: Candidate Behavior, Campaign Discourse, and Democracy (Cambridge: Cambridge University Press, 2002); Harold D. Clarke., David Sanders, Marianne C. Stewart and Paul F. Whiteley, Political Choice in Britain (Oxford: Oxford University Press, 2004); 
on issues such as economic growth, management of services, reducing crime - those issues which do not divide candidates and citizens - vote choice is based upon which candidate or party will be most likely to deliver: on competence. ${ }^{3}$

Despite the importance of these theories, there is a gap in our understanding of how public ratings of party issue competence vary over time, and how voters formulate evaluations on competence. This article proposes a mechanism through which public issue handling evaluations can be understood and analysed. An example serves to illustrate the point. Prior to 11 September 2001 (9/11) President George W. Bush had a positive rating on foreign affairs of 54 per cent (July 2001, Gallup). In a subsequent poll, in October, those ratings had increased to 81 per cent (also Gallup). However, Bush's ratings also increased, in significant measure, on social security (41 per cent to 54 per cent), on the economy ( 54 per cent to 72 per cent), on federal budget handling (46 per cent to 59 per cent), and on the environment (50 per cent to 54 per cent). Voters used their general evaluation of President Bush, and his handling of the terror attacks, to inform their evaluation of his policy competence on other issues. In this article we suggest that when voters make a judgement about a candidate or party's rating on one issue they 'transfer' that rating to other issues, via the transmission of useful and relevant information onto other issues, or via an information short-cut or heuristic. We theorize that events and economic shocks lead to changes in competence ratings across issues, via this process of transfer, and incumbent parties incur costs of governing across the issue domain during their period in office. Furthermore, if voters form a generalized rating of party competence across many issues, this broad evaluation should have implications for vote choice. Common movement is indicative of an important tide, or mood, in public opinion.

Data scarcity has made the analysis of public opinion on policy competence problematic until now. In this article, party issue competence evaluations are analysed over time in Britain using data collated from a wide range of polling and election study sources, providing measures spanning from 1950 to 2008, comprising 2,383 issue competence questions in total. Stimson's dyad ratios algorithm is employed to estimate the proportion of variation in competence ratings explained by a dominant dimension of common variation in issue competence, or 'macro-competence'. ${ }^{4}$ The method allows us to

(F'note continued)

Harold D. Clarke., David Sanders, Marianne C. Stewart and Paul F. Whiteley, Performance Politics and the British Voter (Cambridge: Cambridge University Press, 2009).

3 Donald Stokes, 'Spatial Models and Party Competition', American Political Science Review, 57 (1963), 368-77; Donald Stokes, 'Valence Politics', in Dennis Kavanagh, ed., Electoral Politics (Oxford: Clarendon Press, 1992), pp. 141-62.

${ }^{4}$ James A. Stimson, Public Opinion in America: Moods, Cycles, and Swings (Boulder, Col.: Westview, 1991), pp. 60-3. The algorithm has been used to generate aggregate estimates of public left-right policy preferences across time in both the United States (Stimson, Public Opinion in America; James A. Stimson, Michael B. MacKuen and Robert S. Erikson, 'Dynamic Representation', American Political Science Review, 89 (1995), 543-65; Robert S. Erikson, Michael B. MacKuen and James A. Stimson, The Macro Polity (Cambridge: Cambridge University Press, 2002)) and in Britain (John Bartle, Sebastian Dellepiane and James A. Stimson, 'The Moving Centre: Preferences for Government Activity in Britain, 1950-2005', British Journal of Political Science (2011), 259-85), and has been used by a number of other political scientists to construct indices that tap common variance in social and political attitudes (e.g., Robert H. Durr, John B. Gilmour and Christina Wolbrecht, 'Explaining Congressional Approval', American Journal of Political Science, 41 (1997), 175-207; Robert H. Durr, Andrew D. Martin and Christina Wolbrecht, 'Ideological Divergence and Public Support for the Supreme Court', American Journal of Political Science, 44 (2000), 768-76; Virginia A. Chanley, Thomas Rudolph and Wendy M. Rahn. 'The Origin and 
extract a longitudinal measure of issue competence for the first time. This dimension is subjected to scrutiny in the article by a variety of means. We explore the degree to which macro-competence is driven by leader ratings, by events, economic shocks and evaluations, the costs of governing, and by partisanship, and analyse the substantive effect of introducing macro-competence into vote choice models, controlling for existing aggregate-level covariates. The findings are consistent with the proposed theoretical mechanisms, and highlight the potential application of the concept and measure of macro-competence in Britain, and potentially beyond.

The potential applications of macro-competence are four-fold. (i) Estimation of a consistent index of issue competence provides an empirical opportunity to explain variation in party competence, with contextual variation by party and by time. (ii) The finding and concept of common variation in issue competence ratings may revise our understanding of political opportunities for candidates and parties. If issue competence ratings vary in common, we may usefully consider party opportunities as a function of broad competence ratings, rather than issue-specific evaluations. (iii) Macro-competence may exhibit important interactions with other indicators, such as spatial variables, partisanship and so on, offering a range of new theoretical and empirical questions to be explored. (iv) The estimation of macro-competence may offer a new explanatory variable in aggregate level models of vote choice. This article thereby offers a measure of competence which extends existing analysis, and offers new theoretical insights into public opinion about competence.

\section{ISSUES, CAMPAIGNS AND COMPETENCE}

Scholars acknowledge that parties and candidates should prime voters to cast their votes on the basis of their most advantageous issues, via weighting of these issues in the electoral calculation. Conversely, parties should diminish the salience of issues on which an opponent holds an advantage. ${ }^{5}$ Parties and candidates have different utilities which vary by party and which vary by policy issue. The received wisdom implies, therefore, that voters judge parties and candidates on different issues in different ways, according to whether those issues and utilities are positive or negative for the party and the voter. The characteristics of an advantageous issue may relate to spatial proximity, ${ }^{6}$

(F'note continued)

Consequences of Public Trust in Government: A Time Series Analysis', Public Opinion Quarterly, 64 (2000), 239-57; Paul M. Kellstedt, 'Media Framing and the Dynamics of Racial Policy Preferences', American Journal of Political Science, 44 (2000), 245-60; Luke J. Keele, 'Macro Measures and Mechanics of Social Capital', Political Analysis, 13 (2005), 139-56; Luke J. Keele, 'Social Capital and the Dynamics of Trust in Government', American Journal of Political Science, 51 (2007), 241-54; Will Jennings, 'The Public Thermostat, Political Responsiveness and Error-Correction: Border Control and Asylum in Britain, 1994-2007', British Journal of Political Science, 39 (2009), 847-70).

${ }^{5}$ Budge and Farlie, Explaining and Predicting Elections, p. 226; Budge, 'The Internal Analysis of Election Programmes' pp. 15-38; Budge et al., Mapping Policy Preferences; Shanto Iyengar and Donald R. Kinder, News that Matters: Television and American Opinion (Chicago: University of Chicago Press, 1987); Jacobs and Shapiro, 'Issues, Candidate Image, and Priming'; James M. Enelow and Melvin J. Hinich, 'A New Approach to Voter Uncertainty in the Downsian Spatial Model', American Journal of Political Science, 25 (1981), 483-93; Lynn Vavreck, The Message Matters: The Economy and Presidential Campaigns (Princeton, N. J.: Princeton University Press, 2009), pp. 15-25.

${ }^{6}$ Enelow and Hinich, 'A New Approach to Voter Uncertainty in the Downsian Spatial Model'; Vavreck, The Message Matters, p. 19. 
or to competence, trust, delivery and commitment. ${ }^{7}$ The latter features are particularly salient when valence issues dominate the agenda. ${ }^{8}$ Another facet of competence relates to 'ownership'. 9 The concept of ownership refers to associations of parties with issues, generated via long-term commitments and reputations. Therefore, the weighting of issues to the vote depends on whether spatial, valence or 'owned' issues dominate the agenda. These theories overlap with work on the electoral effects of the state of the economy, ${ }^{10}$ and with retrospective voting models. ${ }^{11}$ If a candidate has a positive track record on the economy and the economy is performing well, an incentive exists to prime the issue in campaigns. The economy, and other issues, will therefore be weighted in the vote calculation if the issue is (a) salient to voters, and (b) given prominence to the vote choice. Studies have also analysed the salience of issues such as foreign policy, and its effects on presidential approval, ${ }^{12}$ the electoral consequences of presidential handling of war, ${ }^{13}$ and crime levels and economic mismanagement upon trust in government. ${ }^{14}$ For recent British elections, Clarke et al. report the effects of a broad spectrum of issues upon vote choice. ${ }^{15}$ Their theory combines performance ratings with experience of various policies and services and with emotions towards those experiences.

Each of these literatures provides valuable insights into issue proximity, issue competence and issue priming or weighting and their implications for different parties' incentives. However, none considers the relationships of performance ratings between issues, and whether performance judgements on one issue may contaminate judgements on others. Work on economic voting has not, to our knowledge, explicitly considered the effects of economic downturns upon broader competence ratings on different issues, and the consequences of such a transfer of information. Studies of presidential performance in foreign affairs and in war have not yet considered the effects of these factors upon how a president is rated on the economy, or other issues, and whether these considerations are relevant. It is plausible, we suggest, that these relationships and evaluations are inexorably connected. We know that publics lack information about politics and yet still make coherent political judgements via the use of heuristics and short-cuts. ${ }^{16}$ According

\footnotetext{
${ }^{7}$ Budge and Farlie, Explaining and Predicting Elections; Budge, 'The Internal Analysis of Election Programmes'.

${ }^{8}$ Stokes, 'Spatial Models and Party Competition'; Jane Green, 'When Voters and Parties Agree: Valence Issues and Party Competition', Political Studies, 55 (2007), 629-55; Clarke et al., Political Choice in Britain; Clarke et al., Performance Politics and the British Voter, pp. 30-52.

${ }^{9}$ Petrocik, 'Issue Ownership in Presidential Elections'; Petrocik et al., Issue 'Ownership and Presidential Campaigning'.

${ }^{10}$ See Michael S. Lewis-Beck and Mary Stegmaier, 'Economic Determinants of Electoral Outcomes', Annual Review of Political Science, 3 (2000), 183-219, for a review.

${ }^{11}$ Morris P. Fiorina, Retrospective Voting in American National Elections (New Haven, Conn.: Yale University Press, 1981).

${ }^{12}$ John H. Aldrich, John Sullivan and Eugene Borgida, 'Foreign Affairs and Issue Voting: Do Presidential Candidates "Waltz Before A Blind Audience?" American Political Science Review, 83 (1989), $123-41$.

${ }^{13}$ Jon A. Krosnick and Laura A. Brannon, 'The Impact of the Gulf War on the Ingredients of Presidential Evaluations: Multidimensional Effects of Political Involvement', American Political Science Review, 87 (1993), 963-75.

${ }^{14}$ Chanley et al., 'The Origin and Consequences of Public Trust in Government'.

${ }^{15}$ Clarke et al., Political Choice in Britain; Clarke et al., Performance Politics and the British Voter.

${ }^{16}$ Samuel L. Popkin, The Reasoning Voter: Communication and Persuasion in Presidential Campaigns (Chicago: University of Chicago Press, 1991); Paul Sniderman, Richard Brody and Philip Tetlock, Reasoning and Choice: Explorations in Political Psychology (Cambridge: Cambridge University Press,
} 
to Campbell et al. the vast majority of voters rely on general judgements of which party will be dependable or capable, and do not form independent evaluations of candidates on individual policies. ${ }^{17} \mathrm{We}$ suggest here that performance on one issue provides a heuristic to form competence evaluations on others. Heuristics are at the heart of mass belief systems and we similarly expect them to drive evaluations of government and opposition party performance.

\section{A THEORY OF MACRO-COMPETENCE}

Forming reliable judgements about specific issue and policy performance, delivery and likely handling of different parties, places particularly high cognitive demands upon voters. If voters are asked to evaluate the incumbent on different policy areas it must be questionable whether they always answer with respect to performance and success on one individual issue, or whether they rely upon other heuristics and cues. This must be particularly true for opposition parties, where handling judgements are based upon hypothetical evaluations in the future or performance in the past. ${ }^{18}$

We suggest two routes through which competence judgements are formed. First, we expect that experience with an issue and performance of the government will guide voters on some issues, but these experiences and judgements will be transferred to expectations and ratings on others. Transfer of competence judgements may occur when salient events or economic shocks alter public perceptions of party or candidate competence. A major event such as an economic shock or an unpopular war will introduce performance ratings into the public's mind, providing a heuristic with which to judge the party on many other issues. Secondly, we expect that these ratings accumulate with time in office, and so the costs of government accentuate the effect of heuristics for the incumbent party or candidate.

\section{The Transfer of Competence Ratings across Issues}

Research in social psychology reveals the way citizens form their opinions about politics, via the use of heuristics. ${ }^{19}$ Heuristics represent the short-cuts or cues voters use to overcome cognitive burdens of information. Zaller and Feldman note, 'the making of these judgements requires an aggregation of one's feelings across frequently diverse concerns'. ${ }^{20}$ Heuristics may be particularly useful for evaluating performance. Voters undoubtedly have informed experiences and perceptions of policy outcomes, and their success (or failure) on a number of policy issues. However, it must be doubted whether voters possess information to evaluate government or potential party performance across

(F'note continued)

1991); John Zaller, The Nature and Origins of Mass Opinion (Cambridge: Cambridge University Press, 1992).

17 Angus Campbell, Philip E. Converse, Warren E. Miller and Donald E. Stokes, The American Voter (New York: Wiley, 1960); also Philip E. Converse, 'The Nature of Belief Systems in Mass Publics', in D.E. Apter, ed., Ideology and Discontent (London, Ont.: Macmillan, 1964).

18 Fiorina, Retrospective Voting in American National Elections.

19 Amon Tversky and Daniel Kahneman, 'Judgment Under Uncertainty: Heuristics and Biases', Science, 185 (1974), 1124-31; Amon Tversky and Daniel Kahneman, 'Judgment Under Uncertainty: Heuristics and Biases' in Daniel Kahneman, Paul Slovic and Amos Tversky, eds., Judgment Under Uncertainty: Heuristics and Biases (Cambridge: Cambridge University Press, 1982), pp. 3-22.

${ }^{20}$ John Zaller and Stanley Feldman, 'A Simple Theory of the Survey Response', American Journal of Political Science, 36 (1992), 579-616, p. 609. 
all areas of policy, or instead whether evaluations represent 'an aggregation of one's feelings' about a party's ability to govern.

If we assume that voters exhibit opinions about party handling and competence on a range of issues, even those on which they may be poorly informed, individuals may acquire these judgements using information about high profile issues, using issues salient to them, or issues on which a party has a strong reputation. The British Labour government's decision to enter the war in Iraq and the controversy over its judgement eroded trust in the broader agenda of the government among large numbers of voters. ${ }^{21}$ As other issues rise in salience, voters are provided with high profile cues to signal the competence of the government. The economy is a classic example. Economic shocks may be relatively short-lived, moving issue handling judgements in the short term. Other shocks may introduce considerable persistence and long-term memory into ratings of issue competence and offer voters reliable information about competence on other issues. When the British Conservative government presided over the Exchange Rate Mechanism crisis (in September 1992) the party lost its reputation for economic competence for more than a decade. Its issue handling ratings declined across the issue agenda. ${ }^{22}$ Such 'extraordinary' events can have fundamental consequences for competence evaluations. ${ }^{23}$ The effect of shocks on competence evaluations can either persist indefinitely or decay over time and political judgements tend to exhibit at least some long-term persistence. ${ }^{24}$ Economic crises may also have the psychological effect of biasing respondent judgements of parties, punishing an incumbent across a range of evaluations, as well as at the ballot box. Voters may use information about long-standing party reputations to inform their evaluations. If a left-of-centre party is more trusted on welfare issues, unemployment and public services, and a right-of-centre party is more trusted on crime, immigration and the economy, those associations may provide information to voters about new and other issues. If a party loses ownership of an issue on which it is trusted, it could be more severely rated on other issues as well. ${ }^{25}$ Thus, we suggest that voters use cues on certain issues to inform their ratings on others. These processes of issue transfer could arise from rational inference, whereby voters come to a considered conclusion of generalized competence based on high profile policy failure or success and the signal this provides about trust and competence, or they could arise from cognitive economies, whereby voters use information to decide whether a party is trustworthy and a good manager, and assume this is true across the policy domain. Issue transfer is particularly likely considering the agenda-shaping nature of political communications. Candidates and parties focus on their own positive records but they highlight the weaknesses of their

21 Clarke et al., Performance Politics and the British Voter.

22 Jane Green, 'A Test of Core Vote Theories: The British Conservatives, 1997-2005', British Journal of Political Science (forthcoming).

${ }^{23}$ See Charles W. Ostrom Jr and Renée M. Smith, 'Error Correction, Attitude Persistence, and Executive Rewards and Punishments: A Behavioral Theory of Presidential Approval', Political Analysis, 4 (1992), 127-83, p. 132.

24 Robert H. Durr, 'What Moves Policy Sentiment?' American Political Science Review, 87 (1993), 158-70; Janet M. Box-Steffensmeier and Renée M. Smith. 'The Dynamics of Aggregate Partisanship', American Political Science Review, 90 (1996), 567-80; Christopher Wlezien, "An Essay on "Combined" Time Series Processes', Electoral Studies, 19 (2000), 77-93; Harold D. Clarke and Matthew Lebo, 'Fractional (Co)integration and Governing Party Support in Britain', British Journal of Political Science, 33 (2003), 283-301.

25 Petrocik, 'Issue Ownership in Presidential Elections'. 
opponents, accentuating differences with respect to trust and competence. These messages may be particularly influential among voters who hold less information about politics or who are more receptive and attentive to information about a party. ${ }^{26}$ Public opinion on issue competence can also be led through strategic action of elites, where issue evolution leads to partisan realignment or change. ${ }^{27}$

The implication of these expectations is that variability in how individuals view party competence should be similar across diverse policy issues. ${ }^{28}$ When ratings of a party decrease or increase on one issue, they should increase or decrease on others, even issues we might not expect to be related. Therefore, evaluations of party competence should show significant correlations across issues, indicative of an underlying factor or dimension of public opinion. This expectation is expressed in Hypothesis 1:

HYPOTHESIS 1: Issue competence ratings exhibit common variation across diverse policy concerns.

The implication of issue transfer and costs of governing is that a generalized issue competence evaluation underlies different performance judgements on issues. However, issue handling ratings could themselves be proxies for other known and measured evaluations of candidates and parties: such as leader evaluations, party identification and prospective as well as retrospective economic evaluations. These indicators also serve as powerful heuristics to voters, and will inform competence ratings on issues. Therefore, we expect leader ratings, party identification and economic evaluations to exert powerful effects on broad issue competence evaluations. However, if issue competence ratings are also derived from high profile performance failures (and successes), and there is a general tide in competence evaluations unique to policy issues, then this movement in competence ratings should not be synonymous with these. We therefore further expect to find differences in the co-variation of issue competence ratings, leader ratings, economic ratings and party identification, and expect issue competence to exert a distinct impact upon party choice. These questions are explored in this article.

\section{The Costs of Governing upon Issue Competence Evaluations}

If common variation in issue competence evaluations is predicted by heuristics and the transferring of information about performance, then the costs of governing should predict a decline in generalized competence levels with time in office. 'Disappointment is the universal malady ... It is also a basic spring of political change'. ${ }^{29}$

${ }^{26}$ John Zaller, 'Information, Values, and Opinion', American Political Science Review, 85 (1991), 1215-37; John Zaller, The Nature and Origins of Mass Opinion (Cambridge: Cambridge University Press, 1992).

${ }^{27}$ E.g. Edward G. Carmines and James A. Stimson, Issue Evolution: Race and the Transformation of American Politics (Princeton, N.J.: Princeton University Press, 1989).

${ }^{28}$ Note that issue transfer could also arise from measurement artefact. Surveys tend to include batteries of issue handling evaluations when they field questions about policy competence, with different issues listed one after the other. We would expect to find considerable contamination in response (Nathaniel T. Wilcox and Christopher Wlezien, 'The Contamination of Responses to Survey Items: Economic Perceptions and Political Judgments', Political Analysis, 5 (1996), 181-213). Given the possibility of order effects, measures of issue handling ratings should draw upon a range of different items and surveys, as undertaken in the article.

${ }^{29}$ Arthur M. Schlesinger, Jr, The Cycles of American History (Boston: Houghton Mifflin Company, 1986). p. 28. 
The costs of being in government have increasingly negative effects on incumbent party vote shares. ${ }^{30}$ These patterns lead to findings of cyclical patterns in public opinion over time, as governments alternate and public opinion reacts in a similar fashion. ${ }^{31}$ Incumbents often benefit from high ratings when they enter government, which decline with time. A honeymoon period arises as voters discount responsibility in the first months of office, when a new government cannot be held to account for the performance of the previous incumbent. From there on the electorate is more likely to blame an incumbent for its mistakes than to reward it for its successes, ${ }^{32}$ and this dynamic of public opinion offers a mechanism specific to incumbents and time in office. Campbell et al. argue:

As long as public affairs go well, there is little to motivate the electorate to connect events of the wider environment with the actors of politics ... but when events of the wider environment arouse strong public concern the electorate is motivated to connect them with the actors of politics, typically, with the incumbent party. ${ }^{33}$

Downs argues that incumbents are tested more severely for their reliability and responsibility. ${ }^{34}$ The costs of governing and the costs of disappointment should reinforce the effects of contamination and heuristics whereby the public lack information about many aspects of performance but derive ratings from a general perception of declining competence, alternating with the party or candidate in office. These costs of governing are particularly relevant to issue competence or policy competence. ${ }^{35}$ This informs our expectation of a downward trend in policy or issue competence ratings across issues when parties are in power. Their combined force enhances the heuristic of translating general competence ratings across issues. They also suggest that governing parties may be more vulnerable to events and informational shocks than opposition parties, although public knowledge regarding opposition parties will be sufficiently low that heuristics should also be employed. The cost of governing argument does not require parties' issue handling ratings to change in their distribution but to change in level. Ceteris paribus, we expect that a party's competence ratings will decline in office, and this will be common across issues.

HYPOTHESIS 2: Governing parties experience a decline across common issue competence evaluations with length of time in office.

${ }^{30}$ Richard Rose and Thomas T. Mackie, 'Incumbency in Government: Asset or Liability?' in Hans Daalder and Peter Mair, eds., Western European Party Systems: Continuity and Change (Beverley Hills, Calif.: Sage, 1983); Martin Paldam, 'The Distribution of Election Results and the Two Explanations of the Cost of Ruling', European Journal of Political Economy, 2 (1986), pp. 5-24; David Sanders, 'The Political Economy of UK Party Support, 1997-2004: Forecasts for the 2005 General Election', Journal of Elections, Public Opinion \& Parties, 15 (2005), 47-71.

31 Schlesinger, The Cycles of American History; Stimson, Public Opinion in America; Erikson et al., The Macro Polity; Samuel Merrill III, Bernard Grofman and Thomas L. Brunell, 'Cycles in American National Electoral Politics, 1854-2006: Statistical Evidence and an Explanatory Model', American Political Science Review, 102 (2008), 1-17.

32 Christopher Anderson, Blaming the Government: Citizens and the Economy in Five European Democracies (Armonk, N.Y.: M. E. Sharpe, 1995).

33 Campbell et al., The American Voter, p. 556.

34 Anthony Downs, An Economic Theory of Democracy (New York: Harper and Row, 1957), pp. 104-5.

${ }^{35}$ See Arthur H. Miller and Martin P. Wattenberg, 'Throwing the Rascals Out: Policy and Performance Evaluations of Presidential Candidates, 1952-1980', American Political Science Review, 79 (1985), 359-72. 


\section{From Micro-Level Foundations to Macro-Level Mood}

If individuals react to events and broad performance cues and to the costs of governing, transferring their evaluations between issues, we would expect common variation in competence evaluations among the wider electorate. Such an idea of a prevailing sentiment in public opinion is implicit to the understanding of mass opinion.

The idea goes by different names - the national mood, the climate in the country, changes in public opinion, or broad social movements. But common to all of these labels is the notion that a rather large number of people out in the country are thinking along certain common lines, that this national mood changes from one time to another in discernible ways. ${ }^{36}$

The macro-level consequences of the theory of macro-competence give rise to the concept of a mood in competence ratings, or 'macro-competence'. Macro-competence implies the existence of a general sentiment in public opinion towards the activities of parties and candidates manifested in common variation in public evaluations of competence across a range of issues. The national mood, where this refers to 'macrocompetence', arises because events, salient issues, economic shocks and costs of governing shape performance ratings for large numbers of individuals in a common direction. Just as the idea has been applied to left-right preferences, ${ }^{37}$ we propose that competence judgements move in a way consistent with a general mood, akin to the concept of 'parallel publics'. ${ }^{38}$ The work of Tversky and Kahneman on framing likewise suggests that individuals' judgements are often reducible to a single, dominant consideration. ${ }^{39}$ This is the psychological, micro-level basis for the macro-level concept of mood: ${ }^{40}$ changes in individual attitudes drive trends in macro-level opinion - whether or not these shifts in public opinion are heterogeneous or homogeneous. ${ }^{41}$ If change occurs at random, those variations are cancelled out through sampling and measurement over time. Noise, response instability and individual errors are, therefore, removed through aggregation. ${ }^{42}$ Furthermore, the effect of short-term shocks or contamination between issues can accumulate and persist in macro-level processes such as macro-competence, where these belong to a class of 'combined' time-series processes. Changes persist for some individuals and decay for others. ${ }^{43}$ Even if the competence judgements of just a small number of individuals are persistent in future time periods (i.e. are long-memoried), there is also

36 John W. Kingdon, Agendas, Alternatives, and Public Policies (New York: Harper Collins, 1984), p.153.

${ }^{37}$ Stimson, Public Opinion in America, p. 21; Stimson et al., 'Dynamic Representation'; Bartle et al., 'The Moving Centre'.

${ }^{38}$ Benjamin I. Page and Robert Y. Shapiro, The Rational Public (Chicago: University of Chicago Press, 1992), pp. 285-320.

39 Tversky and Kahneman, 'Judgment Under Uncertainty', pp. 3-22.

40 James A. Stimson, 'Public Policy Mood: A Personal Narrative', Political Methodologist: Newsletter of the Political Methodology Section, American Political Science Association, 12 (2004), 9-14, p. 12.

${ }^{41}$ E.g. Philip E. Converse, 'Popular Representation and the Distribution of Information', in John A. Ferejohn and James H. Kuklinski, eds., Information and Democratic Processes (Chicago: University of Illinois Press, 1990), p. 382; Erikson et al., The Macro Polity, p. 5; James A. Stimson, 'The Micro Foundations of Mood', in James H. Kuklinski, ed., Thinking About Political Pyschology (Cambridge: Cambridge University Press, 2002), pp. 253-80, at p. 268; Peter K. Enns and Paul M. Kellstedt, 'Policy Mood and Political Sophistication: Why Everybody Moves Mood', British Journal of Political Science, 38 (2008), 433-54.

${ }^{42}$ Page and Shapiro, The Rational Public, pp. 16-17; Erikson et al., The Macro Polity, p. 6.

${ }^{43}$ See Wlezien, 'An Essay on "Combined" Time Series Processes'. 
persistence at the macro-level - as shocks accumulate and as variance expands over time. The concept of macro-competence, therefore, represents a combination of change and persistence in the competence evaluations of individuals, expressed at a macro-level of aggregation where persistence indicates the extent to which people do - and do not discount the past in their evaluations.

\section{THE MEASUREMENT OF MACRO-COMPETENCE}

The examination of variation in issue competence evaluations is based on data collated in Great Britain. With respect to external validity, the British case is one where we would expect parties to have reputations on issues, similar to other countries in which issue ownership theories have been explored. ${ }^{44}$ Strong reputations may lead to lower common variation providing a strict test of the hypotheses. Great Britain has also informed the pioneering studies in this field. ${ }^{45}$ The British case offers a range of data sources that can be compared across the longest possible time period, between 1950 and 2008. Since 1950 the British polling industry has collectively fielded a range of issue questions, by topic and by wording, relating to handling, competence, performance, effectiveness, trust or delivery. The British Election Study also provides several measures, but no study series has fielded a consistent survey item, and time variant analysis of issue competence has, therefore, not been possible. Time-series data are, however, also available in Britain on party identification, leader ratings, and subjective or objective measures of economic performance, allowing us now to examine the degree to which variation in issue competence is unique to macro-competence.

Stimson's dyad ratios algorithm is used to extract a global dimension of competence evaluations using survey questions from the earliest surveys in Britain in 1950 to the most recent surveys released in $2008 .{ }^{46}$ The algorithm offers a way of examining the conceptual assumptions of the common movement of issue competence as a generic latent construct. Stimson's dyad ratios algorithm also offers a solution to the problem of missing data - in circumstances where 85 per cent of all possible values are missing and where the distribution of data is irregular, and this is therefore ideally suited to issue competence data which has not been collated continuously. ${ }^{47}$

${ }^{44}$ See Petrocik, 'Issue Ownership in Presidential Elections'; Petrocik et al., 'Issue Ownership and Presidential Campaigning; Simon, The Winning Message; Lee Sigelman and Emmett H. Buell, 'Avoidance or Engagement? Issue Convergence in U.S. Presidential Campaigns, 1960-2000', American Journal of Political Science, 48 (2004), 650-61; David F. Damore, 'Issue Convergence in Presidential Campaigns', Political Behavior, 27 (2005), 71-97; John Sides, 'The Origins of Campaign Agendas', British Journal of Political Science, 36 (2006), 407-36; Eric Belanger and Bonnie M. Meguid, 'Issue Salience, Issue Ownership, and Issue-Based Vote Choice', Electoral Studies, 27 (2008), 477-91; Paolo Bellucci, 'Tracing the Cognitive and Effective Roots of "Party Competence": Italy and Britain, 2001', Electoral Studies, 25 (2006), 548-69; Christoffer Green-Pedersen, 'The Growing Importance of Issue Competition: The Changing Nature of Party Competition in Western Europe', Political Studies, 55 (2007), 607-28.

${ }^{45}$ See Ian Budge and Dennis J. Farlie, Voting and Party Competition (London: Wiley, 1977); Budge and Farlie, Explaining and Predicting Elections, p. 226. Budge et al., Strategy and Party Change; Ian Budge, 'The Internal Analysis of Election Programmes', pp. 15-38.

${ }^{46}$ Stimson, Public Opinion in America, pp. 60-3; and Appendix 1, pp. 133-7; Stimson et al., 'Dynamic Representation', p. 548. The earliest recorded question in Britain on the competence of political parties to handle issues, asked by Gallup about housing in 1945, is included in our dataset for historical purposes, but the estimates of macro-competence for the 1945 to 1949 period are excluded due the absence of other poll observations.

${ }^{47}$ Stimson, 'Public Policy Mood', p. 10. 
The dyad ratios algorithm calculates macro-competence as an average of the available observations of positive evaluations of a given party's competence in handling a particular issue (for example, the percentage of respondents rating a party as best to handle the economy or the percentage of respondents rating a party as doing 'quite well' or 'very well' in handling education), at time period $t$, through recursive estimation of dyad ratios (where the dyad ratio is estimated for each pair of cases in which there is an observation of competence evaluation at two points in time), weighted for the degree of common variance of each evaluation with macro-competence itself. This is expressed in the form:

$$
V_{t}=\frac{\sum_{i=1}^{n} \sum_{j=1}^{t} u_{i}^{2} \times \frac{x_{i j}}{x_{i b}} \times M_{b}}{n}
$$

where $i=1, n$ is all available issues on which the public rates a particular party positively on their competence; where $j=1, t$ is all available dyadic comparisons for competence evaluations on an issue $i ; b$ is the base period for the recursive metric; $M_{b}$ is the value of the metric for period $b$; and $u_{i}^{2}$ is an estimated weight for the common variance of competence evaluations, $x_{i}$, and macro-competence mood (which is the squared correlation for each issue with the latent dimension, providing an estimate of indicator validity). The index is then smoothed with an exponential algorithm, $y_{t}=\alpha x_{t}+(1-\alpha) x_{t-1}$, to dampen the volatility of random errors from sampling fluctuations. This calculates macrocompetence $\left(y_{t}\right)$ as a weighted moving average of past $\left(x_{t-1}\right)$ and future values $\left(x_{t}\right)$ of the raw series. The dyad ratios procedure is used here to generate annual estimates of macrocompetence for Labour, the Conservatives and the Liberals for the period between 1950 and $2008(N=59)$ and also quarterly estimates for the period between 1979 and 2008 $(N=118){ }^{48}$

The analyses are based upon a total of 2,383 administrations of 184 different questions by five survey organizations (Gallup, Ipsos-MORI, Populus, YouGov and the British Election Study) about evaluation of party competence to handle particular issues or problems (for a summary see Appendix, Table A1). ${ }^{49}$ For a question to be included in the mood index it must be asked at least twice. The mean number of question administrations is equal to 13.2 (with a standard deviation of 16.2). Most of the questions require respondents to choose between Labour, the Conservatives or (in the majority of instances) the Liberals/Liberal Democrats, with the option of a non-response ('none' or 'don't know') ${ }^{50}$ A small number $(N=104)$ of questions from the British Election Study refer to the issue competence of a single political party (typically that in government). Overall, a good proportion of the competence questions (728) relate to the economy

\footnotetext{
48 Note that we do not extend the data to the analysis of the Liberal Democrats in the coalition government, 2010 onwards, and so the estimates relate to the party in opposition, with the short-lived exception of the Lib-Lab pact in 1977.

${ }^{49}$ Some wording of some Gallup and Ipsos-MORI questions included ask the public which party has the 'best policies' to deal with a particular issue (e.g., 'Which party has the best policies on ... managing the economy?'). To confirm that these questions are capturing evaluations of competence the macrocompetence series is also estimated excluding these questions. For the period from 1977 to 2000, during which there was most overlap of question wordings, pairwise correlations of these alternative measures of macro-competence are strong and significant for all the parties - Labour $\left(0.87^{* * *}\right)$, Conservative $\left(0.79^{* * *}\right)$ and Liberals $(0.82 * * *)$ - capturing the same issue competence.

${ }^{50}$ This means that the Conservative mood index is estimated from 2,317 observations, the Labour index from 2,345 observations and the Liberal index from 2,106 observations.
} 
TA B L 1 Summary Statistics of Net Difference between Survey Questions on Competence and Monthly Vote Intention (Absolute Values)

\begin{tabular}{lrrr}
\hline \hline & Conservative & Labour & Liberals \\
\hline Min & 0.00 & 0.00 & 0.00 \\
Max & 41.66 & 45.39 & 35.90 \\
Mean & 9.46 & 11.31 & 10.07 \\
Standard Deviation & 5.89 & 7.33 & 4.95 \\
$N$ & 2,317 & 2,345 & 2,106 \\
\hline \hline
\end{tabular}

(30.6 per cent, of which 179 concern unemployment, 117 taxation and 432 the economy in general). However, the majority of the questions are non-economic (69.4 per cent).

The questions do not stimulate pure partisan responses since competence questions from the same month can diverge from vote intention by as much as up to 45 per cent (see Table 1). For example, in September 2007 just 5 per cent of respondents named the Conservatives as the party with the best policies to handle animal welfare (with 66 per cent answering 'don't know'). It is, therefore, possible for competence evaluations to tend towards zero despite partisan bias. (The possibility of partisan bias is also dealt with further in a later section of this article).

The mean difference between issue competence ratings and vote intention in a given month is equal to 9.5 per cent for the Conservatives, 11.3 per cent for Labour and 10.1 per cent for the Liberals. Using the recursive dyad ratios algorithm we explore three questions.

First, we ask, what proportion of variance is explained by the extraction of macrocompetence mood? Stimson's algorithm extracts two dimensions, a first dimension (which we name macro-competence) and a second dimension, and calculates the proportion of variance explained by each. ${ }^{51}$ In this analytical step, we provide illustrative evidence of movements in macro-competence, by party, over the time frame between 1950 and 2008.

Secondly, disaggregating macro-competence mood, we ask, do all issues load similarly onto macro-competence and by party? This is central to our argument regarding issue transfer, which predicts that different issues will form a generalized competence rating, since they share common ratings and variation, even across diverse policy issues. ${ }^{52} \mathrm{We}$ compute, essentially, issue 'sub-moods' using the same technique by issue area, to extract a longitudinal value of party competence on each issue category over time. This provides an average competence value, by party, for eight issue categories, ${ }^{53}$ and enables us to explore whether there is transfer across issues.

We then seek to account for what moves macro-competence, to test our theoretical expectations regarding events, economic shocks and costs of governing, and also to question the degree to which macro-competence is a unique and distinct measure, rather than a proxy for leader evaluations, economic evaluations or party identification.

51 Stimson, Public Opinion in America, pp. 60-3.

52 For example, a party may naturally be rated positively on similar public service issues, because performance on one may be mirrored on another, but common variation on issues such as crime and healthcare, or defence and education, would be more indicative of evidence of transfer or the use of competence cues.

${ }^{53}$ We also compute an extra category, 'other'. The categories are substantively meaningful but also need to be sufficiently large, over 50 years, to allow for reliable estimation. 
We exploit a range of analyses to evaluate the extent to which macro-competence is distinct to partisanship, leader ratings and the economy, and to verify whether the extracted measure is biased due to question composition. Finally, we examine the statistical power of macrocompetence in a vote model which includes a range of aggregate variables known to move vote intention.

\section{RESULTS: MACRO-COMPETENCE IN THE UNITED KINGDOM, 1950-2008}

The application of the dyad ratios algorithm suggests that there is a strong underlying latent dimension in the public's evaluations of issue competence. The method extracts the central tendency of survey items relating to competence, analogous to a principal components approach. For each item, the algorithm calculates how much variance is shared with the latent dimension and the strength of its loading onto each possible dimension of macro-competence. This loading is interpretable as a factor score. The first dimension of macro-competence explains 63 per cent of all variance in the observed public ratings of issue competence of the Conservatives, 54 per cent for Labour and 70 per cent for the Liberals. Given that poll data on issue competence are drawn from right across the issue spectrum, this is a noteworthy finding.

The second dimension of macro-competence explains a far smaller proportion of common movement in issue ratings: with 13 per cent of variance explained for the Conservatives, 18 per cent for Labour and 10 per cent for the Liberals. The first dimension represents, therefore, the greatest proportion of common variance, and is large in comparison with other similar indices. Bartle et al. find a first dimension of left-right preferences in Britain accounting for around 48 per cent variance, with 5 per cent on the second. ${ }^{54}$ Stimson's analysis of left-right mood in the United States found a first dimension accounting for 27 per cent of the variance, and 14 per cent of variance for the second. ${ }^{55}$

We note that the proportion of variance in competence ratings explained by macrocompetence is robust to the issues used to estimate the index. For example, if we remove all economic issues from macro-competence, the proportion of variance accounted for is equal to 61 per cent for the Conservatives, 54 per cent for Labour and 68 per cent for the Liberal Democrats. If we remove just those issues which are more highly rated on average for Labour or the Conservatives, respectively (excluding the Liberals who do not have a higher rating on any issue), then the proportion of variance accounted for is equal to 75 per cent for the Conservatives and 56 per cent for Labour. Conversely, for issues on which these two parties are more negatively rated on average, the proportion of variance accounted for by macro-competence is equal to 68 per cent for the Conservatives and 65 per cent for Labour. These tests suggest that the common transfer of issue competence ratings is present between more positively and negatively rated issues, and is not simply attributable to perceptions of the economic competence of parties. ${ }^{56}$

${ }^{54}$ Bartle et al., 'The Moving Centre'.

${ }^{55}$ Stimson, Public Opinion in America, see online files.

${ }^{56} \mathrm{We}$ also checked the substantive meaning of the measure to be confident that macro-competence is capturing valence, not positional policy preferences. We calculated the correlation coefficient of macrocompetence with a version of macro-competence that excluded MORI's 'party with the best policies' survey items, in case these items were tapping policy preferences and exerting a substantively significant effect. This made little difference, with the two measures correlated above 0.80 in a period when the sample consisted equally of items relating to 'handling' and 'best policies'. We also calculated the correlation coefficient of macro-competence with public policy mood (Bartle et al., 'The Moving Centre'); 
TABLE 2 Correspondence between Alternative Specifications of Macro-Competence, $1950-2008$

\begin{tabular}{lccc}
\hline \hline & \multicolumn{3}{c}{ Macro-competence } \\
\cline { 2 - 4 } & Conservative & Labour & Liberals \\
\hline Macro-competence, no economic issues & $0.96^{* * *}$ & $0.88^{* * * *}$ & $0.97^{* * *}$ \\
Macro-competence, high rated issues & $(59)$ & $(59)$ & $(59)$ \\
Macro-competence, low rated issues & $0.80^{* * *}$ & $0.93^{* * *}$ & - \\
& $(56)$ & $(59)$ & - \\
\hline \hline
\end{tabular}

$* p \leq 0.05, * * p \leq 0.01, * * * p \leq 0.001$.

Table 2 presents the correlations of our overall construct of macro-competence, which includes all available issues, with these alternative specifications, and Figure 1 displays the pattern of the first and second dimensions of macro-competence for each party in the United Kingdom between 1950 and 2008.

The fluctuations displayed in Figure 1 offer plausible relationships with the events and outcomes of British politics. The Conservatives' macro-competence index shows a relatively consistent value prior to the 1990s, although with fluctuations, such as prior to election losses in the mid 1960s, and again in 1974, and also in the early 1980s prior to the Falklands War. There is a clear and sustained drop in macro-competence in the early 1990s - the period following Britain's withdrawal from the European Exchange Rate Mechanism (ERM), and internal dissent over the Maastricht Treaty, as well as the replacement of Prime Minister Margaret Thatcher by John Major. It is only in the final data points that macro-competence moves in a clear upwards direction, as David Cameron neared the general election of 2010. The second dimension mirrors the first for the most part, but appears to diverge during the 1980s and drop more slowly following the Conservative party's difficulties in the 1990s. As Conservative popularity declined under Margaret Thatcher and then John Major, its second dimension, accounting for a small amount of variation, performed relatively better than the first. For Labour the macro-competence index reveals sharp drops in 1968 (prior to the Conservative Edward Heath gaining power) and between 1983 and 1987, when the Labour party split and the party was led by Michael Foot. The party's competence index reaches an all-time high in the period preceding Labour's landslide victory in 1997, and subsides under Gordon Brown in the latter time points. The second dimension for Labour corresponds closely with the first, appearing to improve more slowly for the party during the 1990s, therefore representing a converse trend for the Conservatives during this period. The macrocompetence index is interesting and intuitive for the Liberal Democrat party. Macrocompetence is consistently low and there is little variation in the second dimension other than exhibiting a gradual decline over time. There is a peak in the first dimension during

(F'note continued)

a comparable measure of respondent's left-right preferences, and found substantively low correlations with macro-competence. 

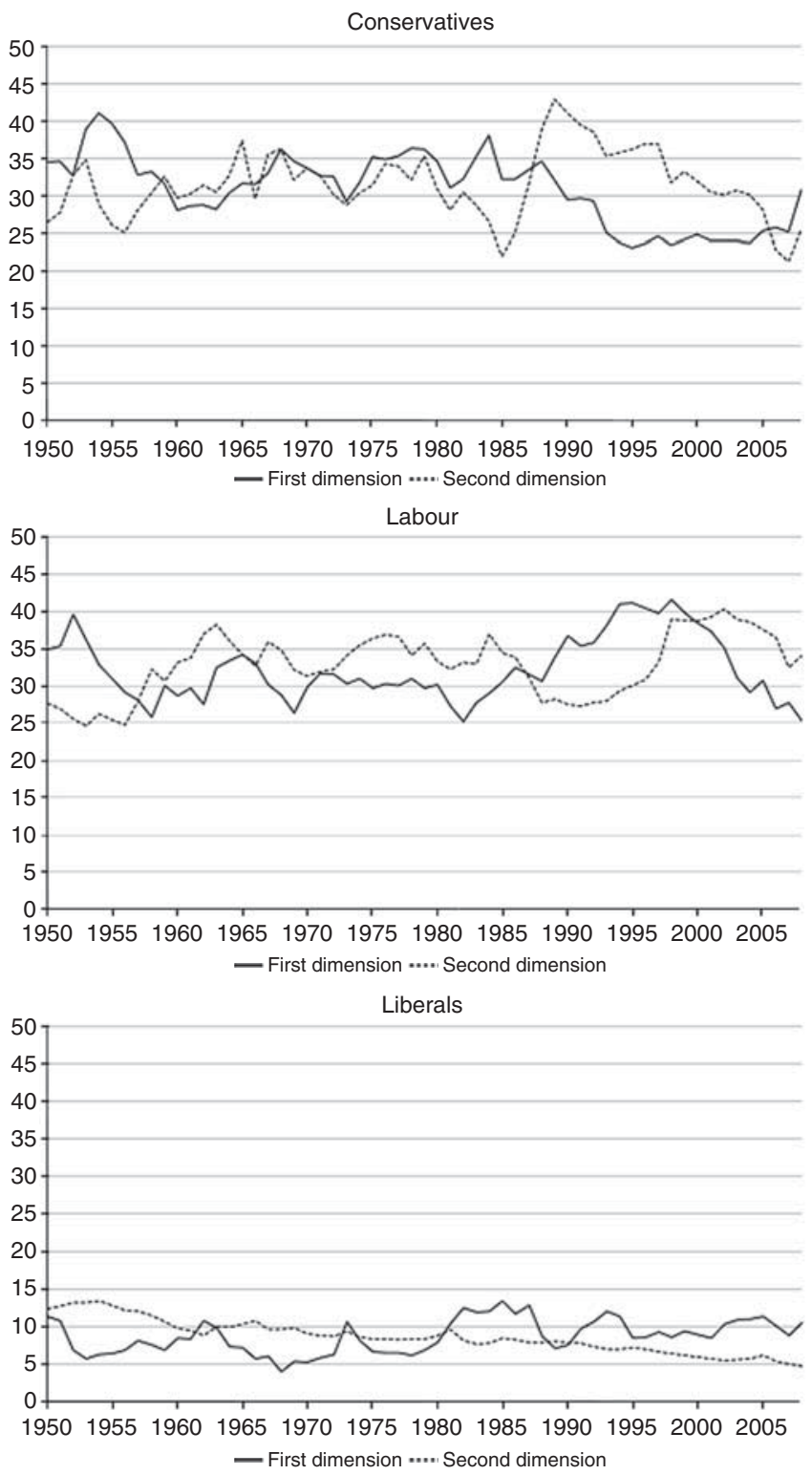

Fig. 1. Macro-competence in the Britain, 1950-2008

the 1983 to 1987 period when the Social Democrat Party (the break-away party from Labour) and the existing Liberals formed the SDP-Liberal Alliance.

We examine the loading of issues onto both dimensions. This provides substantive interpretation of the indices, and of the first and second dimensions, and allows us to ascertain whether there is common variation across a range of issues relating to each dimension, which would be consistent with transfer, or common variance arising from generalized competence heuristics. Issue competence ratings are broken down into issue categories using the dyad ratios algorithm. The categories are aggregated thematically to 
allow for sufficient sample sizes. Summary statistics for the competence ratings comprising each category are presented in the Appendix in Table A3. Pairwise correlations of issue subcategories with macro-competence are presented in Table 3. These correlations are interpretable as a factor loading onto the underlying mood construct. ${ }^{57}$ The correlations reveal the degree to which the prevailing public mood about party competence is linked to competency ratings on different issues.

The factor loadings for all categories load onto the first dimension for at least one party, and a diverse range of issues load strongly across each party. These findings provide support for our expectation that variation in competence ratings will be common across diverse issues, as predicted by the first hypothesis. The strongest loading items for the Conservatives are the economy, crime, welfare, pensions and housing, health and education, and Europe. The evaluation of Conservative competence on the first dimension, therefore, draws upon issues from a wide spectrum, including issues with which it might be expected to be strongly associated, such as Europe and crime, and issues which the party may not be thought typically to 'own', such as health and education. The strongest factor loadings for Labour are unemployment, crime, and health and education. These issues include those on which Labour might be expected to have a stronger reputation for competence, such as unemployment and public services, but also includes an issue that is typically recognized as being strong for the Conservatives, crime. The factor loadings onto the first dimension for the Liberal Democrats are very high across all issues, suggesting that heuristics are particularly useful for third parties, for whom knowledge of competence is less readily available. For all parties some issues drive overall competence ratings to a greater degree than others. Parties may have greater incentives to manage their evaluations on these issue categories. However, there is strong evidence of a common underlying dimension in public ratings of party competence.

There is not as much common variance across issues upon the second dimension. In general the loadings are less strong, and they include positive and negative loadings onto macro-competence. It is notable that all loadings are negative for the Liberal Democrat second dimension. There is some evidence pointing to correspondence of the second dimension of macro-competence with issues a party traditionally owns, ${ }^{58}$ particularly since the Liberals would not be considered to own specific issues ahead of other parties. The Conservative second dimension exhibits positive loading for issues on which it has a reputation for competence, Europe, crime, and defence (and foreign affairs and terrorism), and negative ratings on typical 'Labour issues', health, education, welfare, pensions and housing. However, this interpretation does not hold for the loadings of issues onto the second dimension for Labour, where there is a similar, though not identical, pattern of loadings as for the Conservatives. The loading of competence ratings is positive for Labour on Europe, defence, foreign affairs and terrorism, and negative for its traditionally owned issues, such as welfare, pensions, housing, health and education. The loading of economic issues is also negative, which is more consistent with the traditional disadvantage of Labour on managing the economy. These loadings may arise because the salience and strategic benefit of issues change over the time period, because these issues represent a foreign versus domestic issues dimension, or the second dimension may capture additional variation that is specific to each party.

57 Stimson, Public Opinion in America, Appendix 1, pp. 133-7.

58 Petrocik, 'Issue Ownership in Presidential Elections'; Petrocik et al., 'Issue Ownership and Presidential Campaigning'. 
TA B LE 3 Factor Loadings of Competence on Specific Issues on Macro-Competence $\dagger$

\begin{tabular}{|c|c|c|c|c|c|c|}
\hline & \multicolumn{6}{|c|}{ Macro-competence } \\
\hline & \multicolumn{2}{|c|}{ Conservative } & \multicolumn{2}{|c|}{ Labour } & \multicolumn{2}{|c|}{ Liberals } \\
\hline & $\begin{array}{c}\text { First } \\
\text { Dimension }\end{array}$ & $\begin{array}{c}\text { Second } \\
\text { Dimension }\end{array}$ & $\begin{array}{c}\text { First } \\
\text { Dimension }\end{array}$ & $\begin{array}{c}\text { Second } \\
\text { Dimension }\end{array}$ & $\begin{array}{c}\text { First } \\
\text { Dimension }\end{array}$ & $\begin{array}{c}\text { Second } \\
\text { Dimension }\end{array}$ \\
\hline Economy (incl. Taxation and Inflation) & $\begin{array}{c}0.939 * * * \\
(56)\end{array}$ & $\begin{array}{c}0.128 \\
(56)\end{array}$ & $\begin{array}{r}0.278^{*} \\
(56)\end{array}$ & $\begin{array}{c}-0.288^{*} \\
(56)\end{array}$ & $\begin{array}{c}0.869 * * * \\
(56)\end{array}$ & $\begin{array}{c}-0.763 * * * \\
(56)\end{array}$ \\
\hline Unemployment & $\begin{array}{c}0.590 * * * \\
(52)\end{array}$ & $\begin{array}{c}0.168 \\
(52)\end{array}$ & $\begin{array}{c}0.775^{* * * *} \\
(52)\end{array}$ & $\begin{array}{r}-0.123 \\
(52)\end{array}$ & $\begin{array}{c}0.721 * * * \\
(52)\end{array}$ & $\begin{array}{r}-0.003 \\
(52)\end{array}$ \\
\hline Crime & $\begin{array}{c}0.832 * * * \\
(50)\end{array}$ & $\begin{array}{l}0.378 * * \\
(50)\end{array}$ & $\begin{array}{c}0.617 * * * \\
(50)\end{array}$ & $\begin{array}{r}0.153 \\
(50)\end{array}$ & $\begin{array}{c}0.698^{* * * *} \\
(50)\end{array}$ & $\begin{array}{c}-0.290^{*} \\
(50)\end{array}$ \\
\hline Europe & $\begin{array}{c}0.787 * * * \\
(46)\end{array}$ & $\begin{array}{c}0.397 * * \\
(46)\end{array}$ & $\begin{array}{r}0.182 \\
(46)\end{array}$ & $\begin{array}{c}0.384 * * \\
(46)\end{array}$ & $\begin{array}{c}0.906^{* * * *} \\
(46)\end{array}$ & $\begin{array}{r}-0.226 \\
(46)\end{array}$ \\
\hline Health \& Education & $\begin{array}{c}0.768 * * * \\
(50)\end{array}$ & $\begin{array}{c}-0.449 * * \\
(50)\end{array}$ & $\begin{array}{c}0.817 * * * \\
(50)\end{array}$ & $\begin{array}{c}-0.362 * * \\
(50)\end{array}$ & $\begin{array}{c}0.892 * * * \\
(50)\end{array}$ & $\begin{array}{c}-0.647 * * * \\
(50)\end{array}$ \\
\hline Welfare, Pensions \& Housing & $\begin{array}{c}0.847 * * * \\
(59)\end{array}$ & $\begin{array}{c}-0.286^{*} \\
(59)\end{array}$ & $\begin{array}{c}0.491 * * * \\
(59)\end{array}$ & $\begin{array}{c}-0.427 * * * \\
(59)\end{array}$ & $\begin{array}{c}0.853 * * * \\
(59)\end{array}$ & $\begin{array}{c}-0.471 * * * \\
(59)\end{array}$ \\
\hline Defence, Foreign Affairs \& Terrorism & $\begin{array}{c}0.723 * * * \\
\quad(55)\end{array}$ & $\begin{array}{c}0.318^{*} \\
(55)\end{array}$ & $\begin{array}{c}0.464 * * * \\
(55)\end{array}$ & $\begin{array}{c}0.409^{* *} \\
(55)\end{array}$ & $\begin{array}{c}0.666^{* * * *} \\
(55)\end{array}$ & $\begin{array}{r}-0.233 \\
(55)\end{array}$ \\
\hline Strikes, Employment \& Labour Relations & $\begin{array}{c}0.549 * * * \\
(49)\end{array}$ & $\begin{array}{c}0.269 \\
(49)\end{array}$ & $\begin{array}{c}0.199 \\
(49)\end{array}$ & $\begin{array}{r}-0.139 \\
(49)\end{array}$ & $\begin{array}{c}0.744 * * * \\
(49)\end{array}$ & $\begin{array}{c}-0.429 * * \\
(49)\end{array}$ \\
\hline Other & $\begin{array}{c}0.586^{* * * *} \\
(58)\end{array}$ & $\begin{array}{r}-0.006 \\
(58)\end{array}$ & $\begin{array}{r}0.277^{*} \\
(58)\end{array}$ & $\begin{array}{c}-0.519 * * * \\
(58)\end{array}$ & $\begin{array}{c}0.494 * * * \\
(58)\end{array}$ & $\begin{array}{c}-0.759 * * * \\
(58)\end{array}$ \\
\hline
\end{tabular}

$\dagger N$ in parentheses. ${ }^{*} p \leq 0.05, * * p \leq 0.01, * * * p \leq 0.001$. 
Overall, the findings reveal a dominant underlying first dimension in competence evaluations which is driven by ratings on many issues, for all three main parties, suggesting that a relatively small proportion of variation, a second dimension, is driven by issue-specific strengths and weaknesses. Public ratings of party competence exhibit common variation for the most part, indicative of the mechanism of heuristics and transfer of ratings across issues.

We next turn to the question of what moves the dominant first dimension of macrocompetence for each party, and seek to determine the degree to which this common variation supports the theoretical hypotheses as well as the degree to which macrocompetence is distinct from other political dispositions or judgements.

\section{RESULTS: WHAT MOVES MACRO-COMPETENCE?}

The micro-foundations of macro-competence - the accumulation of issue competence ratings across issues (transfer), in response to shocks and over time in office - all suggest that there is persistence in underlying dimensions of political judgements about the competence of political parties, at the aggregate level. Persistence represents the rate at which competence evaluations return to their long-term equilibrium in response to disturbances. ${ }^{59}$ We examine the temporal structure and the costs of governing for annual estimates of macro-competence over the full period between 1950 and 2008.

\section{Costs of Governing}

In order to first test the long-term persistence of macro-competence on a year-by-year basis, we estimate an autoregressive distributed lag (ADL) model. This specification measures the overall degree of persistence of macro-competence, controlling for the cost of governing, where macro-competence in a given year $\left(C O M P E T E N C E_{t}\right)$ is estimated as a function of its value in the previous year $\left(C O M P E T E N C E_{t-1}\right)$, and a pair of count variables control for the number of years the party is in government (TIME IN GOV $V_{t}$ ) or the number of years in opposition (TIME IN $\left.O P P_{t}\right)$. This count variable is coded as 0 during the first year of office of a government (opposition) and after this adds 1 for each successive year of government (opposition), reset to 0 when a party is voted out of office (voted into power). The ADL takes the form:

$$
\begin{aligned}
\text { COMPETENCE }_{t}= & \alpha_{0}+\beta_{1} \text { COMPETENCE }_{t-1}+\beta_{2} \text { TIME IN GOV }_{t} \\
& +\beta_{3} \text { TIME IN OPP } t+\varepsilon_{t} .
\end{aligned}
$$

The results of this model are presented in Table 4.

Parties' ratings for competence in handling issues are highly persistent, as suggested by the autoregressive character of macro-competence. The lagged value of macro-competence indicates that around 85 per cent of last years' value is carried forward to the following year (this is rather lower for the Liberals, at around 75 per cent). Substantively, if Labour or the Conservatives achieve a 1 per cent boost in their competence ratings, 0.44 per cent remains some five years later. ${ }^{60}$ There is long-term memory, then, in macro-competence for all parties. The coefficient is lower for the Liberals, as might be expected, but is also indicative of persistence.

\footnotetext{
${ }^{59}$ See Ostrom and Smith, 'Error Correction, Attitude Persistence, and Executive Rewards and Punishments', pp. 131-3.

${ }^{60}$ That is: $(1 \times 0.85 \times 0.85 \times 0.85 \times 0.85 \times 0.85)$.
} 
TABLE 4 An Autoregressive Distributed Lag Model of Macro-Competence and the Costs of Governing, 1950-2008

\begin{tabular}{lccc}
\hline \hline & \multicolumn{3}{c}{ Macro-competence $_{t}$} \\
\cline { 2 - 4 } & Labour & Conservative & Liberal \\
\hline Macro-Competence $_{t-1}$ & $0.867^{* * *}$ & $0.873^{* * *}$ & $0.759^{* * *}$ \\
& $(0.062)$ & $(0.068)$ & $(0.085)$ \\
Time in Government $_{t}$ & $-0.181 \dagger$ & $-0.140^{*}$ & - \\
Time in Opposition & $(0.105)$ & $(0.065)$ & - \\
& 0.089 & $(0.001$ & $2.129)$ \\
Constant & $(0.058)$ & $4.436 \dagger$ & $(0.767)$ \\
& $4.096^{*}$ & $(2.352)$ & 1950 \\
Start & $(2.040)$ & 1950 & 59 \\
End & 1950 & 2008 & 0.577 \\
$N$ & 2008 & 59 & 1.208 \\
Adjusted $R^{2}$ & 59 & 0.803 & 1.245 \\
Durbin-Watson $h$-statistic & 0.791 & 0.192 & 0.075 \\
Breusch-Godfrey $(1)$ & 0.024 & 0.209 & 1.081 \\
ARCH $\chi^{2}(1)$ & 0.027 & & \\
\hline \hline
\end{tabular}

$* p \leq 0.05, * * p \leq 0.01, * * * p \leq 0.001, \dagger p \leq 0.1$.

The results indicate that time in government has a negative and significant effect upon macro-competence, as hypothesized, which is significant at the 95 per cent level for the Conservatives (and at the 90 per cent level for Labour). For each year the Conservatives are in government they lose 0.14 points from their macro-competence rating. Their mean level of macro-competence over the entire period is 31.2 (see Table A3), equating to around 0.5 per cent of their average level, amounting to a 2.5 per cent drop over the course of a full five year parliament. Time in opposition is not significant, indicating that the costs of governing upon macro-competence are not symmetrical for governing and opposition parties. This is a substantively interesting finding and one which warrants further research. For the purposes of this article, the finding provides support for the theoretical mechanism hypothesized of the common decline in competence over time, across a broad spectrum of policy issues.

\section{Events as Competence Information}

Political and economic events provided another mechanism through which we argued that informational shocks facilitate the common transfer of competence evaluations. We therefore consider the effects on macro-competence of a selection of important events in British politics from past studies of vote choice and those we suggest may influence perceptions of competence. ${ }^{61}$ These are the founding of the Social Democratic Party

${ }^{61}$ Harold D. Clarke and Marianne C. Stewart, 'Economic Evaluations, Prime Ministerial Approval and Governing Party Support: Rival Models Reconsidered', British Journal of Political Science, 25 (1995), 145-70; Harold D. Clarke, Karl Ho and Marianne C. Stewart, 'Major's Lesser (Not Minor) Effects: Prime Minister Approval and Governing Party Support in Britain since 1979', Electoral Studies, 19 
(SDP) in 1981, the Falklands War in 1982, the miners' strikes of 1984, the merger of the SDP and Liberal Party in 1988, the poll tax riots in March 1990, the commencement of Operation Desert Storm during the Gulf War in 1991, the Exchange Rate Mechanism crisis in September 1992, the Iraq War in 2003 (when evidence for weapons of mass destruction was discredited) and the run on the Northern Rock bank in 2007, which signalled the start of the financial crisis in Britain. In order to estimate the effects of events, we use quarterly data. There are insufficient underlying poll data to produce reliable estimates of macro-competence at monthly intervals, so our analyses cannot detect the effect of events with the precision that is possible using monthly data, but quarterly data are clearly preferable to annual for the analysis of events. The analysis spans the third quarter of 1979 and the fourth quarter of 2008. The ADL model takes the general form:

$$
\begin{aligned}
\text { COMPETENCE }_{t}= & \alpha_{0}+\beta_{1} \text { COMPETENCE }_{t-1}+\beta_{2} \text { COMPETENCE }_{t-2} \\
& +\beta_{3} \text { TIMEIN GOV }_{t}+\beta_{4} \text { EVENTS }_{t}+\varepsilon_{t} .
\end{aligned}
$$

The effects of events on macro-competence are estimated as a step intervention ${ }^{62}$ and we omit the term for time in opposition in light of the earlier results. The model also includes the second lag of macro-competence (COMPETENCE $\left.E_{t-2}\right)$ to control for serial autocorrelation in the Conservative model. ${ }^{63}$ The results are reported in Table 5.

There is again a considerable degree of persistence in issue competence ratings, with the positive and significant effect of the first lag equal to 0.70 for Labour, 0.89 for the Conservatives and 0.78 for the Liberals. This indicates that the shocks to macrocompetence accumulate and are persistent even in the short term, using quarterly data. The second lag is negative and significant for the Conservatives, indicating a cyclical dynamic affecting macro-competence at this level of temporal aggregation, offsetting the initial persistence. Substantively, there is a stronger reaction to an initial shock of macrocompetence as it tends back towards its longer-term equilibrium level, consistent with the findings for the annual level. Also, the cost of governing variable is no longer significant, suggesting that at least to some extent costs of governing are represented by major events of the period.

The results are consistent with our expectations regarding the way in which macrocompetence - the shared variation in issue competence ratings - responds to important political events. The Falklands War had a positive and significant effect on Conservative macro-competence, while the Miners' Strike of 1984 and the ERM crisis of November 1992 each had a negative and significant effect on Conservative competence (at the 90 per cent and 95 per cent confidence levels, respectively). The ERM crisis also had a positive effect on Labour's macro-competence, benefiting the party's recovery prior to the 1997 election. In similar fashion, the run on Northern Rock in 2007 had a positive effect on macro-competence for the Conservative opposition. Creation of the SDP in

(F'note continued)

(2000), 255-73; Harold D. Clarke and Matthew Lebo, 'Fractional (Co)integration and Governing Party Support in Britain', British Journal of Political Science, 33 (2003), 283-301.

${ }^{62}$ This indicates that the effect of an intervention is permanent after time $t_{j}$, so $E V E N T_{j}=0$ if $t<t_{j}$; $E V E N T_{j}=1$ if $t \geq t_{j}$.

${ }^{63}$ Note that the same inferences are drawn if the second lag of macro-competence is not included, but the diagnostic tests indicate the presence of serial autocorrelation. 
TABle 5 An Autoregressive Distributed Lag Model of Macro-Competence, the Costs of Governing and Events, 1979-2008

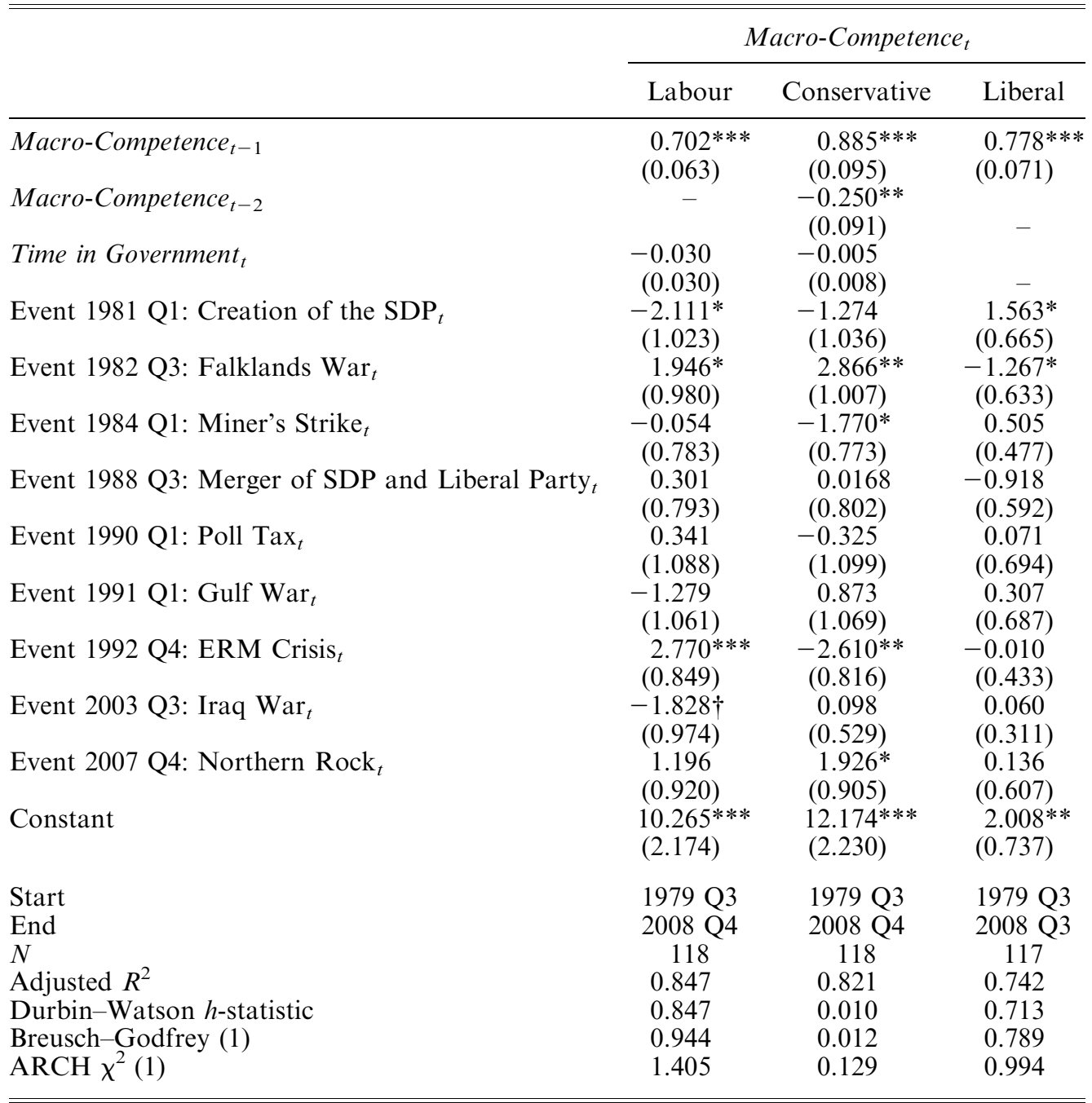

$* p \leq 0.05, * * p \leq 0.01, * * * p \leq 0.001, \dagger p \leq 0.1$.

1981 resulted in an increase in competence evaluations of the party to emerge from the formation and alliance with the Liberals, the Liberal-SDP Alliance, at the same time as resulting in a significant decrease in Labour macro-competence. Important salient events can have immediate and lasting effects on the competence ratings of parties across the issue spectrum.

\section{Macro-Competence and Its Correlates}

We next examine the relationship between macro-competence and other important indicators of party support, namely leader ratings, economic expectations and partisanship, 
used in leading studies of macro-level determinants of the vote (leader ratings, ${ }^{64}$ personal economic expectations ${ }^{65}$ and macro-partisanship ${ }^{66}$ ). We expect these variables to be associated with macro-competence but we also crucially expect the persistence of macrocompetence to remain significant, even controlling for them. Within the running tally view of party identification, macro-competence may offer an indicator of variations in party identification. ${ }^{67} \mathrm{We}$ seek to explore the degree to which macro-competence tells us something unique about public opinion which cannot be encapsulated by existing measures. The data is again at a quarterly level, between 1979 and 2008. The additional covariates are based upon data collated as follows.

Prime ministerial and leader approval. A number of overlapping measures are combined using the dyad ratios algorithm to control for house sampling or question wording effects in different data sources. ${ }^{68}$ Public opinion about satisfaction with the performance of prime ministers and opposition leaders has been measured in regular surveys by both Gallup and Ipsos-MORI. For example, Ipsos-MORI asks the questions: 'Are you satisfied or dissatisfied with the way X is doing his/her job as Prime Minister?' and 'Are you satisfied or dissatisfied with the way $\mathrm{X}$ is doing his/her job as leader of the Conservative/Labour/Liberal Party?' Each series has a factor loading of 0.99 onto the combined measure.

Macro-partisanship. The analyses employ an annual measure of macro-partisanship, estimated once again using the dyad ratios algorithm. The data were compiled by Bartle et $a l$. and have been supplemented by us here. ${ }^{69}$ The data represent the percentage of respondents indicating political affiliation to Labour, the Conservatives, Liberals and

${ }^{64}$ Clarke et al., 'Economic Evaluations, Prime Ministerial Approval and Governing Party Support', pp. 45-170; Robert S. Erikson and Christopher Wlezien, 'Forecasting the Presidential Vote, 1992', Political Methodologist, 5 (1994), 10-11; Robert S. Erikson and Christopher Wlezien, 'Of Time and Presidential Election Forecasts', PS: Political Science and Politics, 29 (1996), 37-9; Harold D. Clarke, Marianne C. Stewart and Paul Whiteley, 'Tory Trends: Party Identification and Conservative Support Since 1992', British Journal of Political Science, 26 (1997), 299-318; Clarke et al., 'Major's Lesser (Not Minor) Effects'; Clarke and Lebo, 'Fractional (Co)integration and Governing Party Support in Britain'; Matthew Lebo and Helmut Norpoth, 'The PM and the Pendulum: Dynamic Forecasting of British Elections', British Journal of Political Science, 37 (2007), 71-87; Matthew J. Lebo and Everett Young, 'The Comparative Dynamics of Party Support in Great Britain: Conservatives, Labour and the Liberal Democrats', Journal of Elections, Public Opinion \& Parties, 19 (2009), 73-103.

${ }^{65}$ See Michael B. MacKuen, Robert S. Erikson and James A. Stimson, 'Peasants or Bankers? The American Electorate and the U.S. Economy', American Political Science Review, 86 (1992), 597-611; David Sanders., Hugh Ward, David Marsh and Tony Fletcher, 'Government Popularity and the Falklands War: A Reassessment', British Journal of Political Science, 17 (1987), 281-313; David Sanders, 'Economic Performance, Management Competence and the Outcome of the Next General Election', Political Studies, 44 (1996), 203-31; David Sanders, 'Conservative Incompetence, Labour Responsibility and the Feelgood Factor: Why the Economy Failed to Save the Conservatives in 1997', Electoral Studies, 18 (1999), 251-70; Clarke and Stewart, 'Economic Evaluations, Prime Ministerial Approval and Governing Party Support'.

${ }^{66}$ Larry Bartels, 'Partisanship and Voting Behavior, 1952-1996', American Journal of Political Science, 44 (2000), 35-50; Bartle et al., 'The Moving Centre'.

67 Fiorina, Retrospective Voting in American National Elections.

68 There are 865 survey items for Labour (Gallup 1946-2000, $N=539$; Ipsos-MORI 1979-2008, $N=326), 846$ items for the Conservatives (Gallup 1951-2000, $N=530$; Ipsos-MORI 1979-2008, $N=326$ ) and 805 items for the Liberals (Gallup 1957-2000, $N=413$; Ipsos-MORI 1979-2008, $N=392$ ).

69 Bartle et al., 'The Moving Centre'. 
other parties. For example, the British Election Study asks, 'Generally speaking, do you see yourself/think of yourself as Labour, Conservative (etc.), or what?'

Personal economic expectations. The analyses employ a range of measures, again combined using the dyad ratios algorithm. For example, the feel-good factor question, or personal economic expectations (PEXP), was surveyed from 1974 by Gallup and asked about expectations for the household: 'Do you consider the financial situation of your household in the next 12 months is likely to ...', with responses 'get a lot better', 'a little better', etc. Personal economic expectations have been an important staple of numerous studies in Britain. ${ }^{70}$ Gallup ceased asking this question in 2001 and, following Sanders, ${ }^{71}$ we use YouGov data to complete the series. Using the dyad ratios algorithm, each series has a factor loading of 1.00 onto the combined measure. The analyses are also crosschecked using objective economic conditions. These are the economic misery index, equal to the national rate of inflation plus the rate of unemployment, and the Conference Board leading and coincident economic indicators.

The dynamic effect of these predictors upon macro-competence is estimated using an error-correction model (ECM). While error-correction is isomorphic with the concept of cointegration, ${ }^{72}$ the model specification is appropriate for modelling short-run and longrun relationships in the context of stationary as well as non-stationary data. ${ }^{73}$ An ECM simply represents a linear reparameterization of the ADL model, used earlier, but allows us to more readily model how the relationship responds to disequilibrium. ECMs are well established in models of dynamics of party support in Britain. ${ }^{74}$ The model allows us to

70 Sanders et al., 'Government Popularity and the Falklands War'; David Sanders, 'Economic Performance, Management Competence and the Outcome of the Next General Election', Political Studies, 44 (1996), 203-31; Sanders, 'Conservative Incompetence, Labour Responsibility and the Feelgood Factor'; David Sanders, 'The Real Economy and the Perceived Economy in Popularity Functions: How Much Do Voters Need to Know?' Electoral Studies, 19 (2000), 275-94.

71 David Sanders, 'The Political Economy of UK Party Support, 1997-2004: Forecasts for the 2005 General Election', Journal of Elections, Public Opinion \& Parties, 15 (2005), 47-71.

${ }^{72}$ Robert F. Engle and Clive W.J. Granger, 'Co-integration and Error Correction: Representation, Estimation and Testing', Econometrica, 55 (1987), 251-76.

${ }^{73}$ Nathaniel Beck, 'Comparing Dynamic Specifications: The Case of Presidential Approval', Political Analysis, 3 (1991), 51-87; Suzanna De Boef and Luke Keele, 'Taking Time Seriously', American Journal of Political Science, 52 (2008), 184-200, pp. 189-90. In this form ECMs are linear re-parameterizations of the ADL models used earlier (see Anindya Banerjee, Juan Dolado, J. W. Galbraith and David Hendry, Integration, Error Correction, and the Econometric Analysis of Non-Stationary Data (Oxford: Oxford University Press, 1993).

74 E.g., Clarke and Stewart, 'Economic Evaluations, Prime Ministerial Approval and Governing Party Support', pp. 145-70; Harold D. Clarke., Marianne C. Stewart and Paul F. Whiteley, 'New Models for New Labour: The Political Economy of Labour Party Support, January 1992-April, 1997', American Political Science Review, 92 (1998), 559-75; Clarke et al., 'Major's Lesser (Not Minor) Effects'. All the ECM models presented in this article were also estimated using the Engle-Granger two-step method which produced similar, if not identical, results. The direction and significance of coefficients were also consistent in models of fractional cointegration estimated using the three-step method (see Clarke and Lebo, 'Fractional (Co)integration and Governing Party Support in Britain'; Lebo and Norpoth, 'The PM and the Pendulum'; Lebo and Young, 'The Comparative Dynamics of Party Support in Great Britain'). Although the effects of error-correction and macro-competence were stronger in the fractional cointegration framework, this also introduced serial autocorrelation into the models. We present the single equation ECMs because our analyses are focused on short-run and long-run effects. Also, the knifeedge problems of tests for stationarity are more severe when dealing with quarterly data, subject to greater persistence than underlying disaggregated data (see Marco Lippi and Lucrezia Reichlin, 'Trend-Cycle 
test the persistence in macro-competence when these covariates are included, and to estimate their relative effects upon variation in macro-competence. This is represented in the form of a single equation ECM. In the single equation ECM, the lagged value of the dependent variable, macro-competence (COMPETENCE $\left.E_{t-1}\right)$, measures the rate of reequilibration in response to shocks to its long-run equilibrium. If the error-correction parameter $\left(\beta_{1}\right)$ is equal to $-0.5,50$ per cent of an initial shock to the previous year's level of macro-competence persists in the subsequent year, 25 per cent in the year after that $(0.5 \times 0.5)$, and so on. The higher the rate of error-correction, the more persistent ratings of macro-competence are in the long term in response to shocks. The model is represented in the following equation:

$$
\begin{aligned}
& \triangle \text { COMPETENCE }_{t}=\alpha_{0}+\beta_{1} \text { COMPETENCE } E_{t-1}+\beta_{2} \text { COMPETENCE }_{t-2} \\
& +\beta_{3} \Delta L E A D E R_{t}+\beta_{4} L E A D E R_{t-1}+\beta_{5} \Delta P A R T Y I D_{t} \\
& +\beta_{6} P A R T Y I D_{t-1}+\beta_{7} \Delta P E X P_{t}+\beta_{8} P E X P_{t-1}+\beta_{9} \Delta G O V_{t} \\
& +\beta_{10} G O V_{t-1}+\beta_{11} \Delta\left(P E X P_{t}^{*} G O V_{t}\right)+\beta_{12} P E X P_{t-1} * G O V_{t-1} \\
& +\beta_{13} \text { TIMEIN GOV } V_{t}+\varepsilon_{t} \text {. }
\end{aligned}
$$

Short-run changes in macro-competence $\left(\triangle C O M P E T E N C E_{t}\right)$ are estimated as a function of short-run changes in leader ratings $\left(\triangle L E A D E R_{t}\right)$, macro-partisanship $\left(\triangle P A R T Y I D_{t}\right)$ and personal economic expectations $\left(\triangle P E X P_{t}\right)$, and lagged long-run values of each of the independent variables $\left(L E A D E R_{t-1}, P A R T Y I D_{t-1}, P E X P_{t-1}\right)$. The second lag of macro-competence (COMPETENCE $\left.E_{t-2}\right)$ is included in the error-correction model for Labour and the Conservatives to remove serial autocorrelation, also capturing re-equilibration in response to shocks. The model includes the short-run and long-run interaction term of personal economic expectations with party control of government $\left(\triangle\left(P E X P_{t}{ }^{*} G O V_{t}\right), P E X P_{t-1}{ }^{*} G O V_{t-1}\right)$ with the constitutive terms $\left(\triangle G O V_{t}, G O V_{t-1}\right)$. The constitutive term is a dichotomous variable $\left(G O V_{t}\right)$, coded as 1 when a party is in government and coded as 0 when it is in opposition. As such, the short-run effect $\left(\Delta G O V_{t}\right)$ tests whether a party's macro-competence decreases when it enters office, while the long-run effect $\left(G O V_{t-1}\right)$ tests whether there is a systematic difference between the level of macro-competence for a party when it is in government compared to the level when it is in opposition. We would expect voters to reward (punish) governing parties for any improvements (deteriorations) in their personal economic circumstances, and hence the model estimates the effect of economic conditions for parties in government.

The results of this ECM model of macro-competence are reported in Table 6. The error-correction component is negative and significant for the second lags for Labour and the Conservatives (and for the first lag at the 90 per cent confidence level) and for the first lag for the Liberals. ${ }^{75}$ Macro-competence ratings last quarter have an equilibrating

\section{(F'note continued)}

Decompositions and Measures of Persistence: Does Time Aggregation Matter?' Economic Journal, 101 (1991), 314-23). Over-differencing can introduce a moving average into the estimates but such an approach is not problematic if appropriate diagnostic tests are completed (see Charles I. Plosser and G. William Schwert, 'Estimation of a Non-Invertible Moving Average Process: The Case of Overdifferencing', Journal of Econometrics, 6 (1977), 199-224). The diagnostics and robustness checks conducted indicate that use of the single equation method does not present a threat to inference.

${ }^{75}$ The Durbin-Watson d-statistic for each of the models does not indicate the presence of serial autocorrelation, with the value approaching 2 in each case. Further, the Breusch-Godfrey test for serial 
TABLE 6 An Error-Correction Model of Macro-Competence

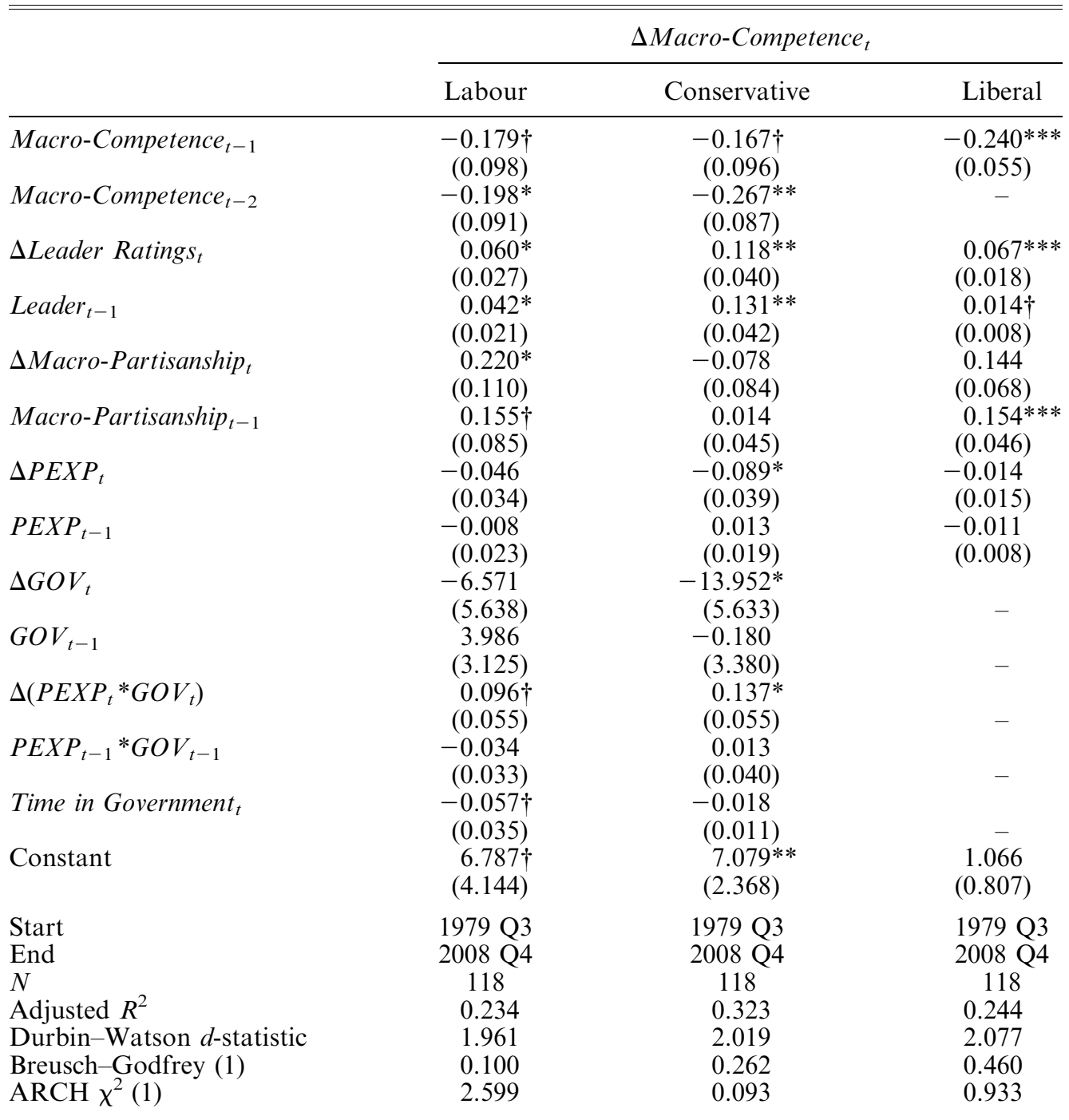

${ }^{*} p \leq 0.05,{ }^{* *} p \leq 0.01,{ }^{* * *} p \leq 0.001 \dagger p \leq 0.1$.

impact on macro-competence ratings today, controlling for other covariates in the model. The parameters indicate that the rate of correction is relatively weak in response to shocks, but this is not surprising given the inclusion of a number of covariates both with positive and significant short-run and long-run effects. The findings denote a systematic degree of persistence in macro-competence. The accumulation of issue competence ratings

(F'note continued)

autocorrelation and Engle's Lagrange multiplier test for the presence of autoregressive conditional heteroscedasticity also generates acceptable values, insignificant at the 95 per cent confidence level. 
across issues remains significant, suggesting that macro-competence captures variation over time that is not reducible to other measures of public opinion and partisan support.

The effects of leader ratings are positive and significant in both the short run and long run for all three parties, and particularly strong for the Conservatives. Leader evaluations are, therefore, important, demonstrating a significant short-run and long-run effect on macro-competence. However, the macro-competence term exhibits persistence alongside these effects, which suggest that evaluations of party leaders are an important predictor of variation in general issue competence evaluations, but they are not a substitute.

Effects of macro-partisanship on macro-competence are significant for Labour and for the Liberals. The measure is constructed from sparser underlying data, which may explain its weaker statistical power in the Conservative model. It is, however, possible that Conservative macro-competence is more strongly related to leader evaluations than to partisan identification during the period between 1979 and 2008. The significance of macro-partisanship in both the Labour and Liberal models provides evidence of the expected relationship between macro-partisanship and macro-competence. Overall, these findings suggest that macro-competence is not simply capturing partisan bias in ratings of which party is best on a range of policy issues.

There is a substantively significant short-run effect of incumbency upon Conservative macro-competence, which may account for the non-significance of time in government in the Conservative model. We find that Labour's macro-competence declines with the period of time in office but only at the 90 per cent confidence level. Furthermore, the interaction of personal economic expectations and party control of government is significant and positive in the short run for the Conservatives, suggesting that economic downturns impact governing party competence ratings, and this is significant for Labour at the 90 per cent confidence level. Overall, the relatively low value of the adjusted $R^{2}$ for each of the parties provides further evidence of the exogeneity of macro-competence to these covariates.

The analysis thus far demonstrates that macro-competence exhibits long-term persistence, robust to the inclusion of other variables. Indeed, it is striking that macro-competence remains robust to the inclusion of the full range of control variables in Table 6.

The unique variation attributable to macro-competence can be explained and accounted for using a simple comparison of the correlations between variables. If macro-competence were simply a proxy for macro-partisanship (for example, resulting from partisan bias driving the first dimension of competence ratings, or representing a running tally measure of party identification $^{76}$ these measures would correlate extremely highly. This could give rise to problems of multicollinearity. In Table 7, we present pairwise correlations of macrocompetence with a number of other political and economic evaluations that are possible proxies (government approval, ${ }^{77}$ leader ratings, macro-partisanship, personal economic expectations).

The correlations presented in Table 7 confirm that while there is some common variance between macro-competence and government approval, leader ratings, macro-partisanship

\footnotetext{
${ }^{76}$ Fiorina, Retrospective Voting in American National Elections.

77 We use overlapping measures of satisfaction with the performance of government. For example, Gallup used to ask, 'Do you approve or disapprove of the Government's record to date?', while IpsosMORI ask, 'Are you satisfied or dissatisfied with the way the Government is running the country?' There are 1,288 survey items concerning government approval (Gallup 1946-2000, $N=519$; Ipsos-MORI 1979-2008, $N=332$; National Opinion Polls 1962-1991, $N=366$; YouGov 2003-2008, $N=71$ ). Note that government approval is not included in the models in Tables 6 and 8, due to overlapping meaning with time in government and the government/opposition dummy. We provide correlations with government approval for substantive interpretation of the correlations.
} 
TABLE 7 Correlations of Macro-Competence with Other Covariates

\begin{tabular}{lccc}
\hline \hline & \multicolumn{3}{c}{ Macro-Competence } \\
\cline { 2 - 4 } & Conservative & Labour & Liberals \\
\hline Government Approval $\times$ Governing Party & $0.659^{* * * *}$ & $0.510^{* * * *}$ & \\
Leader Ratings & $(118)$ & $(118)$ & - \\
& $0.796^{* * *}$ & $0.790^{* * *}$ & $0.411^{* * *}$ \\
Macro-Partisanship & $(118)$ & $(118)$ & $(117)$ \\
& $0.562^{* * *}$ & $0.804^{* * *}$ & $0.606^{* * *}$ \\
Personal Economic Expectations $\times$ Governing Party & $(118)$ & $(118)$ & $(117)$ \\
& $0.469^{* * *}$ & $0.335^{* *}$ & 0.053 \\
& $(118)$ & $(118)$ & $(117)$ \\
\hline \hline
\end{tabular}

$* p \leq 0.05, * * p \leq 0.01, * * * p \leq 0.001, \dagger p \leq 0.1$.

Note: Correlations are tested for interaction of governing party with government approval and personal economic expectations.

and personal economic expectations, in no case are correlations greater than 0.8 . The correlation of macro-partisanship with Labour macro-competence is greater than it is for the Conservatives, a finding that accounts for the significant effect of macro-partisanship in the Labour model in Table 6 but not in the Conservative model. The correlation of leader approval is comparable for both Labour and the Conservatives, and weaker for the Liberals. These correlations denote that while there is likely to be a partisan element to macro-competence (or a macro-competence element to partisanship), and a relationship of leader evaluations to macro-competence, the measures are also conceptually and empirically distinct. The relatively low correlations between macro-competence and the other covariates, personal economic expectations and government approval, suggest that while these constructs are related, they are an important but not sufficient explanation of variations in the ratings of parties on policy issues, as with partisan affiliation and leader evaluations.

We proceed to consider the effect of macro-competence upon vote intention, taking the above covariates into account. If macro-competence reflects a meaningful tide in public opinion, its behavioural consequences will be significant. Furthermore, if we examine the effects of macro-competence alongside other macro-level vote predictors, we gain further purchase upon the unique variance attributable to macro-competence when these predictors are taken into account.

\section{RESULTS: MACRO-COMPETENCE AS A PREDICTOR OF VOTE}

The dynamic short-run and long-run effects of a number of predictors of vote intention are again estimated using a single equation ECM framework for the period between 1979 and 2008. The model is represented by the following equation:

$$
\begin{aligned}
& \Delta \text { VOTE }_{t}=\alpha_{0}+\beta_{1} \text { VOTE }_{t-1}+\beta_{2} \Delta C O M P E T E N C E_{t}+\beta_{3} \text { COMPETENCE }_{t-1} \\
& +\beta_{4} \Delta L E A D E R_{t}+\beta_{5} L E A D E R_{t-1}+\beta_{6} \Delta P A R T Y I D_{t}+\beta_{7} P A R T Y I D_{t-1} \\
& +\beta_{8} \Delta P E X P_{t}+\beta_{9} P E X P_{t-1}+\beta_{10} \Delta G O V_{t}+\beta_{11} G O V_{t-1}+\beta_{12} \Delta\left(P E X P_{t}^{*} G O V_{t}\right) \\
& +\beta_{13} P E X P_{t-1} * G O V_{t-1}+\beta_{14} \text { TIME IN GOV } V_{t}+\varepsilon_{t} \text {. }
\end{aligned}
$$

Short-run changes in party support $\left(\triangle V O T E_{t}\right)$ are estimated as a function of shortrun changes in macro-competence $\left(\triangle C O M P E T E N C E_{t}\right)$, leader ratings $\left(\triangle L E A D E R_{t}\right)$, 
macro-partisanship $\left(\triangle P A R T Y I D_{t}\right)$ and personal economic expectations $\left(\triangle P E X P_{t}\right)$, and lagged, long-run values of each of the independent variables (COMPETENCE $\left.L E A D E R_{t-1}, P A R T Y I D_{t-1}, P E X P_{t-1}\right)$. The model again includes the interaction term of personal economic expectations with party control of government $\left(\triangle\left(P E X P_{t}^{*} G O V_{t}\right)\right.$, $\left.P E X P_{t-1}{ }^{*} G O V_{t-1}\right)$. In this one-step estimation method the lagged value of the dependent variable, party support $\left(V O T E_{t-1}\right)$, measures the rate of re-equilibration in response to shocks to its long-run equilibrium. The results of this model are reported in Table 8 .

The results reveal the substantive and statistical effect of macro-competence on party support. ${ }^{78}$ The estimates confirm that the error-correction component $\left(V O T E_{t-1}\right)$ is negative and significant for each of the parties. This indicates that the rate of correction in response to shocks is of a similar order. Furthermore, macro-competence has a positive and significant short-run effect for each of the parties, and the long-run effect is also positive and significant for the Conservatives (and significant at the 90 per cent confidence level for the Liberals). While the size of effect is of a similar order for Labour and the Conservatives, it is considerably higher for the Liberals, reflecting the fact that Liberal competence evaluations tend, on average, to be well below their party support. Small shifts in issue competence can lead to much larger movements in Liberal support.

The models confirm that there remain positive and significant short-run and long-run effects of leader evaluations on party support for both Labour and the Conservatives, as we would expect. The short-run effect for the Liberals is rather lower, consistent with previous findings on leader effects for the Liberal Democrats. ${ }^{79}$ Likewise, personal economic expectations have a positive long-run effect on support for governing parties, ${ }^{80}$ captured through the interaction term, though greater for Labour than for the Conservatives. The effect of personal economic expectations is significant and negative in both the short run and long run for Labour when out of power, and in the long run for the Conservatives when out of power, indicating that the feel-good factor adversely affects support for both parties when in opposition. Macro-partisanship has a positive and significant long-run effect for the Liberals, but not for the Conservatives or Labour. The effect of time in government over the period between 1979 and 2008 is not significant for Labour or for the Conservatives, most likely because the costs of governing are transmitted through competence evaluations. All these findings for the covariates are consistent with our expectations, but the inclusion of macro-competence in a predictive model of party support provides additional explanatory power. Controlling for additional explanatory variables, the effect of a one-point increase in macro-competence leads to a 0.4 per cent increase in party support in the short run for Labour and 0.3 per cent for the Conservatives (note that this results in more than a 1 per cent increase for the Liberals). These results are substantively significant. They are of a similar magnitude to the effect of leader evaluations (with a one-point increase also leading to a 0.3 per cent increase in party support for Labour and the Conservatives), and stronger in magnitude than the effect of personal economic expectations for governing parties (leading to a 0.3 per cent increase for Labour and a 0.1 per cent increase for the Conservatives). The estimates

\footnotetext{
78 Note that again the Durbin-Watson $d$-statistic and Breusch-Godfrey test for serial autocorrelation and tests for heteroscedasticity all generate acceptable values.

79 Lebo and Young, 'The Comparative Dynamics of Party Support in Great Britain'.

${ }^{80}$ Sanders et al., 'Government Popularity and the Falklands War'; Sanders, 'Economic Performance, Management Competence and the Outcome of the Next General Election'; Sanders, 'Conservative Incompetence, Labour Responsibility and the Feelgood Factor'.
} 
TABLE 8 An Error-Correction Model of Party Support

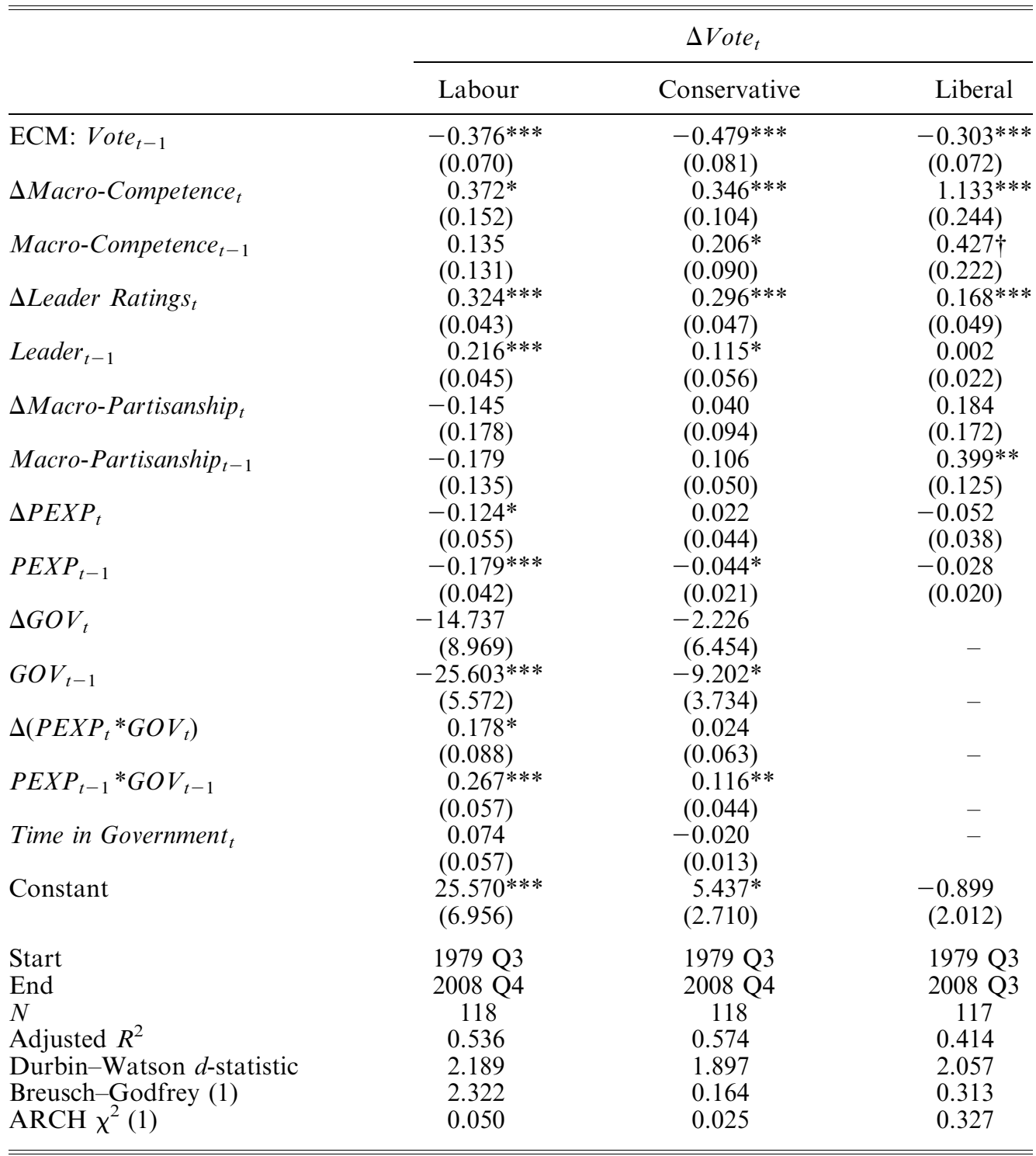

${ }^{*} p \leq 0.05, * * p \leq 0.01, * * * p \leq 0.001, \dagger p \leq 0.1$.

suggest that macro-competence helps to inform models of party choice, and offers a useful measure to understand a significant element of public opinion, with behavioural consequences for party choice in Britain. ${ }^{81}$

${ }^{81}$ Through further robustness checks it is possible to determine the explanatory power of macrocompetence relative to other variables. When macro-competence is dropped from the model of party support a decrease of 5 per cent in the proportion of variance explained (the adjusted $R^{2}$ ) results. The corresponding decrease in the proportion of variance explained is equal to around 2 per cent when 


\section{CONCLUSIONS}

The national mood regarding the competence of parties and candidates is something that people in and around politics and government may sense, talk about and act upon. This general mood arises, we argue, via a process of transfer from one issue judgement to others and via the deployment of heuristics. It is enhanced by events, economic shocks and the costs of governing for incumbent parties. Using Stimson's dyad ratios algorithm ${ }^{82}$ this article identified a dominant dimension of macro-competence, reflecting a general mood among voters in their evaluations of which party is most competent, explaining between 50 per cent and 70 per cent of public issue competence ratings of parties, based on an exhaustive compilation of 2,383 survey administrations between 1950 and 2008 in Britain. While these broad movements in the public mood are affected by leader evaluations, partisan identification, events, economic shocks and time in office, the reputation of political parties for competence across issues are persistent and distinct from leader, partisan and economic effects. Macro-competence also exerts a significant effect upon vote intention in the British electorate.

The measure of macro-competence holds the potential to provide a new empirical opportunity. It overcomes a considerable difficulty, to date, in estimating voters' evaluations of policy competence. While scholars agree that competence, or valence, is highly important, the lack of consistent measurement has meant that these effects have been largely considered through the lens of economic effects, the evaluations of candidates and leaders, and specific effects of individual issues in models of vote choice. The construct may also be estimated in other countries. Combining additional measures of competence, and comparatively, would provide a more comprehensive analysis of constructs of valence and competence.

The findings suggest that we may need to revise conceptions of party incentives and how voters evaluate political parties on competence. Rather than viewing issue strengths as stable, and as separate and distinct variables, we can instead expect a large degree of common variation. These observations may provide fruitful areas for examining the incentives of political elites, most notably the instances of issue dialogue, trespassing or convergence ${ }^{83} \mathrm{We}$ also note that parties may have incentives to campaign on a range of issues because these issues load significantly onto their overall competence evaluations. Macro-competence may, therefore, allow hypotheses to be generated about the degree to which parties wish to maximize their generalized ratings of competence, as well as their issue specific evaluations.

This article has focused upon revealing common variance in issue evaluations. Future work may use the measure as an independent or dependent variable, to explore a number of important research questions. For example, how might political parties improve their competence evaluations? Is there a relationship between spatial policy position and movement of macro-competence? Are there effects of macro-competence on left-right shifts of public opinion over time? Macro-competence exhibits an incumbency effect, and may therefore also help elucidate important cycles of incumbency and party support over time.

\footnotetext{
(F'note continued)

macro-partisanship is dropped, 10 per cent when personal economic expectations and its interaction and constituent terms are dropped, and a 15 per cent drop when leader evaluations and lagged party support are dropped. While macro-competence does not account for as much variance as some other variables, it explains a significant proportion.

${ }^{82}$ Stimson, Public Opinion in America.

${ }^{83}$ Helmut Norpoth and Bruce Buchanan, 'Wanted: The Education President: Issue Trespassing by Political Candidates', Public Opinion Quarterly, 56 (1992), 87-99; Simon, 'The Winning Message'; Sigelman and Buell, 'Avoidance or Engagement?'; Sides, 'The Origins of Campaign Agendas'.
} 
The history of British politics is littered by parties' mishandling of policy issues that have led them to irreparably lose reputations for competence across the board, despite the specificity of most of these failures. The construct of macro-competence can contribute to our understanding of the public's evaluations of political parties and their ability to handle the issues of the day.

APPENDIX

TABLE A $1 \quad$ Questions

\begin{tabular}{lrr}
\hline \hline Questions & Obs. & $\%$ \\
\hline Economy, inflation, prices, interest rates, exchange rates, pound, trade & 432 & 18.13 \\
Taxation & 117 & 4.91 \\
Unemployment & 179 & 7.51 \\
Health, NHS & 177 & 7.43 \\
Immigration, race relations asylum & 75 & 3.15 \\
Labour relations, strikes, trade unions, employment & 184 & 7.72 \\
Education, schools & 170 & 7.13 \\
Environment, climate change & 77 & 3.23 \\
Transport, public transport & 62 & 2.60 \\
Law and order, crime, hanging & 183 & 7.68 \\
Welfare, benefits, pensions, poverty, homelessness & 133 & 5.58 \\
Housing & 63 & 2.64 \\
Defence, international/foreign affairs, nuclear arms/weapons and & & \\
$\quad$ disarmament, Iraq & 201 & 8.43 \\
Northern Ireland, Constitution, Devolution & 31 & 1.30 \\
Europe, EU, Common Market & 123 & 5.16 \\
Terrorism & 10 & 0.42 \\
Other: Animal welfare, ethics, morality, individual freedom, fair society, freedom & & \\
$\quad$ of speech, privacy, party's effectiveness in 'representing its ideas', modernisation, & & \\
$\quad$ national unity, women, young people, democracy, public ownership & 166 & 6.97 \\
Total & 2383 & \\
\hline \hline
\end{tabular}

\section{Sample questions:}

Q. If Britain were in economic difficulties, which party do you think could handle the problem best - the Conservatives or Labour?

Q. Which party do you think can best handle the problem, or isn't there much to choose between them, on the issue of full employment, short-time working?

Q. I am going to read out a list of problems facing the country. Could you tell me for each of them which political party you personally think would handle the problem best? [Pensions]

Q. Irrespective of your own preferences, which party do you think would be most likely to look after Britain's pensioners?

\section{British Election Study 2001 and 2005 Campaign Studies}

2001: How many marks out of 10 would you give the Government for its performance in each of the following areas? (the NHS/taxation/education/the level of crime in Britain)

How do you think a Conservative Government would handle each of the following issues? (the NHS/taxation/education/the level of crime in Britain)

2005: Q. How well do you think the present government has handled (How well do you think a Conservative government would handle): crime in Britain/the number of asylum seekers coming to Britain/ the National Health Service/the risk of terrorism in Britain/the economy in general/the level of taxation? 
TABLE A2 Number of Competence Poll Questions Per Year

\begin{tabular}{|c|c|c|c|c|c|c|}
\hline Year & Gallup & MORI & Populus & YouGov & BES & Total \\
\hline 1945 & 1 & & & & & 1 \\
\hline 1951 & 2 & & & & & 2 \\
\hline 1952 & 1 & & & & & 1 \\
\hline 1953 & 3 & & & & & 3 \\
\hline 1954 & 3 & & & & & 3 \\
\hline 1956 & 5 & & & & & 5 \\
\hline 1957 & 8 & & & & & 8 \\
\hline 1958 & 1 & & & & & 1 \\
\hline 1959 & 22 & & & & & 22 \\
\hline 1961 & 1 & & & & & 1 \\
\hline 1962 & 6 & & & & & 6 \\
\hline 1963 & 2 & & & & 1 & 3 \\
\hline 1964 & 35 & & & & & 35 \\
\hline 1965 & 6 & & & & & 6 \\
\hline 1966 & 28 & & & & 1 & 29 \\
\hline 1967 & 7 & & & & & 7 \\
\hline 1968 & 9 & & & & & 9 \\
\hline 1969 & 18 & & & & & 18 \\
\hline 1970 & 18 & & & & 3 & 21 \\
\hline 1971 & 15 & & & & & 15 \\
\hline 1972 & 9 & & & & & 9 \\
\hline 1973 & 10 & & & & & 10 \\
\hline 1974 & 38 & & & & 9 & 47 \\
\hline 1975 & 31 & & & & & 31 \\
\hline 1977 & & 6 & & & & 6 \\
\hline 1978 & 87 & 10 & & & & 97 \\
\hline 1979 & 47 & 24 & & & 9 & 80 \\
\hline 1980 & 28 & 7 & & & & 35 \\
\hline 1981 & 29 & 8 & & & & 37 \\
\hline 1982 & 27 & 7 & & & & 34 \\
\hline 1983 & 25 & 44 & & & 6 & 75 \\
\hline 1984 & 80 & & & & & 80 \\
\hline 1985 & 96 & 7 & & & & 103 \\
\hline 1986 & 32 & 7 & & & & 39 \\
\hline 1987 & 91 & 41 & & & 5 & 137 \\
\hline 1988 & 22 & 4 & & & & 26 \\
\hline 1989 & 22 & & & & & 22 \\
\hline 1990 & 79 & 16 & & & & 95 \\
\hline 1991 & 82 & 38 & & & & 120 \\
\hline 1992 & 133 & 48 & & & & 181 \\
\hline 1993 & 41 & 13 & & & & 54 \\
\hline 1994 & 40 & 15 & & & & 55 \\
\hline 1995 & 43 & 18 & & & & 61 \\
\hline 1996 & 73 & 28 & & & & 101 \\
\hline 1997 & 121 & 30 & & & 6 & 157 \\
\hline 1998 & 27 & 17 & & & 6 & 50 \\
\hline 1999 & 12 & 16 & & & 6 & 34 \\
\hline 2000 & 55 & 32 & & & 6 & 93 \\
\hline 2001 & & 16 & & & 14 & 30 \\
\hline 2002 & & 16 & & & & 16 \\
\hline 2003 & & 16 & & 12 & & 28 \\
\hline 2004 & & 16 & 7 & 13 & & 36 \\
\hline 2005 & & 13 & 31 & 12 & 35 & 91 \\
\hline 2006 & & 16 & 5 & 8 & & 29 \\
\hline 2007 & & 16 & 7 & 8 & & 31 \\
\hline 2008 & & 13 & 14 & 30 & & 57 \\
\hline Grand Total & 1571 & 558 & 64 & 83 & 107 & 2383 \\
\hline
\end{tabular}


TABLE A3 Summary Statistics of Issue Competence Ratings and Macro-Competence

\begin{tabular}{|c|c|c|c|c|c|c|c|c|c|c|c|c|c|c|c|}
\hline & \multicolumn{5}{|c|}{ Con } & \multicolumn{5}{|c|}{$\mathrm{Lab}$} & \multicolumn{5}{|c|}{ Lib } \\
\hline & $\begin{array}{l}\text { Mean } \\
\text { (S.D.) }\end{array}$ & Poll Q's & Start & End & $\mathrm{N}$ & $\begin{array}{l}\text { Mean } \\
\text { (S.D.) }\end{array}$ & Poll Q's & Start & End & $\mathrm{N}$ & $\begin{array}{l}\text { Mean } \\
\text { (S.D.) }\end{array}$ & Poll Q's & Start & End & $\mathrm{N}$ \\
\hline $\begin{array}{l}\text { Economy (incl. Taxation } \\
\text { and Inflation) }\end{array}$ & $\begin{array}{l}35.40 \\
(9.44)\end{array}$ & 530 & 1953 & 2008 & 56 & $\begin{array}{l}35.03 \\
(9.97)\end{array}$ & 536 & 1953 & 2008 & 56 & $\begin{array}{c}7.52 \\
(3.50)\end{array}$ & 349 & 1953 & 2008 & 56 \\
\hline Unemployment & $\begin{array}{l}23.07 \\
(7.51)\end{array}$ & 179 & 1957 & 2008 & 52 & $\begin{array}{l}43.45 \\
(9.38)\end{array}$ & 175 & 1957 & 2008 & 52 & $\begin{array}{c}8.72 \\
(4.83)\end{array}$ & 175 & 1957 & 2008 & 52 \\
\hline Crime & $\begin{array}{l}39.64 \\
(9.38)\end{array}$ & 178 & 1959 & 2008 & 50 & $\begin{array}{l}26.09 \\
(7.73)\end{array}$ & 178 & 1959 & 2008 & 50 & $\begin{array}{c}7.76 \\
(3.15)\end{array}$ & 173 & 1959 & 2008 & 50 \\
\hline Europe & $\begin{array}{l}36.20 \\
(8.61)\end{array}$ & 123 & 1962 & 2007 & 46 & $\begin{array}{l}26.66 \\
(6.77)\end{array}$ & 123 & 1962 & 2007 & 46 & $\begin{array}{c}8.49 \\
(3.54)\end{array}$ & 123 & 1962 & 2007 & 46 \\
\hline Health \& Education & $\begin{array}{l}23.84 \\
(7.32)\end{array}$ & 331 & 1959 & 2008 & 50 & $\begin{array}{c}43.13 \\
(10.42)\end{array}$ & 342 & 1959 & 2008 & 50 & $\begin{array}{l}11.03 \\
(4.75)\end{array}$ & 326 & 1959 & 2008 & 50 \\
\hline $\begin{array}{l}\text { Welfare, Pensions } \\
\text { \& Housing }\end{array}$ & $\begin{array}{c}23.73 \\
(11.01)\end{array}$ & 194 & 1945 & 2008 & 64 & $\begin{array}{c}43.71 \\
(12.70)\end{array}$ & 196 & 1945 & 2008 & 64 & $\begin{array}{c}7.42 \\
(3.69)\end{array}$ & 194 & 1945 & 2008 & 64 \\
\hline $\begin{array}{l}\text { Defence, Foreign Affairs } \\
\& \text { Terrorism }\end{array}$ & $\begin{array}{c}41.33 \\
(10.61)\end{array}$ & 208 & 1953 & 2007 & 55 & $\begin{array}{l}25.19 \\
(6.14)\end{array}$ & 208 & 1953 & 2007 & 55 & $\begin{array}{c}8.33 \\
(4.18)\end{array}$ & 203 & 1953 & 2007 & 55 \\
\hline $\begin{array}{l}\text { Strikes, Employment } \\
\text { \& Labour Relations }\end{array}$ & $\begin{array}{c}33.89 \\
(11.19)\end{array}$ & 176 & 1956 & 2004 & 49 & $\begin{array}{l}36.80 \\
(8.09)\end{array}$ & 178 & 1956 & 2004 & 49 & $\begin{array}{c}6.59 \\
(3.47)\end{array}$ & 167 & 1956 & 2004 & 49 \\
\hline Other & $\begin{array}{c}23.82 \\
(10.88)\end{array}$ & 398 & 1951 & 2008 & 58 & $\begin{array}{c}31.65 \\
(12.64)\end{array}$ & 409 & 1951 & 2008 & 58 & $\begin{array}{l}10.31 \\
(5.79)\end{array}$ & 396 & 1951 & 2008 & 58 \\
\hline Macro-Competence & $\begin{array}{l}31.18 \\
(4.63)\end{array}$ & 2317 & 1945 & 2008 & 64 & $\begin{array}{l}32.48 \\
(4.24)\end{array}$ & 2345 & 1945 & 2008 & 64 & $\begin{array}{c}8.98 \\
(2.33)\end{array}$ & 2106 & 1945 & 2008 & 64 \\
\hline
\end{tabular}

